\title{
Tradução, patriotismo e a economia política de Portugal Imperial na época Pombalina: as traduções de Les Aventures de Télémaque e dos Élémens du commerce ${ }^{1}$
}

\author{
Monica Lupetti \\ Universidade de Pisa \\ Departamento de Filologia, Literatura e Linguística \\ Marco E.L. Guidi \\ Universidade de Pisa \\ Departamento de Economia e Gestão
}

\begin{abstract}
The paper offers a study of two translations published in 1765-1766 by the same author, José Manuel Ribeiro Pereira, just before being appointed secretary of the Junta da Administração of the Companhia Geral do Grão Pará, e Maranhão, one of the chartered trade companies that had been established by the Marquis of Pombal in 1755. The texts that Pereira translated were Fénelon's Les Aventures de Télémaque, an epic novel full of political and economic admonitions, and Véron de Forbonnais's Élémens du commerce. In a country and at a time in which most of the discussion on political economy was private or an affair of the court, these translations contributed to a public debate on the economic reforms introduced by Pombal at the crucial moment in which, after the Seven Years War (1756-1763), the reinforced alliance with Great Britain and a significant change in her commercial interests seemed to call for a reformulation of Portuguese commercial and industrial strategies. The second
\end{abstract}

\footnotetext{
${ }^{1}$ Este artigo é resultado de dois projetos de pesquisa: o LLP/Erasmus Sub Programme Multilateral Project "EE-T. Economics e-Translations into and from European Languages, An Online Platform" (518297-LLP-12011-IT-ERASMUS-FEXI - 2011-2013) (Projeto Multilateral sub-programa Erasmus/LLP "EE-T. Economia Traduções Eletrônicas para e das Línguas Europeias, uma Plataforma Online"); e um projeto patrocinado pela Universidade de Pisa sobre "A circulação da economia política na Europa nos séculos XVIII e XIX: as traduções de Télémaque de Fénelon", ambos coordenados por Marco Guidi. Os autores agradecem o coordenador do Departamento de Livros Antigos e Raros da Biblioteca Municipal de Viseu, Dra. Teresa Almeida, por sua valiosa ajuda ao disponibilizar uma parte considerável dos materiais impressos nos quais este artigo está baseado, e os/as arquivistas do Arquivo Nacional da Torre do Tombo, Lisboa, por seu conselho gentil e especialista durante nossa pesquisa. Os autores também agradecem Antonella Alimento, José Luis Cardoso, João Paulo Silvestre, Evelina Verdelho e Telmo Verdelho por seus comentários e sugestões em diferentes estágios da sua pesquisa. As isenções de responsabilidade usuais se aplicam. A concepção do artigo, sua introdução e conclusões são comuns a ambos os autores. Entretanto, Monica Lupetti escreveu as seções 2 e 3 e Marco Guidi as seções 4, 5 e 6. Títulos citações foram transcritas de acordo com critérios diplomáticos. Termos e substantivos foram traduzidos somente quando mencionados no decorrer da nossa narração.
} 
edition of the translations of Télémaque, published by Pereira in 1784-1785, was part and parcel of a second wave of public debate on political economy, this time connected to the fundamental question of the future of the institutions created by Pombal, after his dismissal in 1777. Interestingly, the paratext of Pereira's translations open a window on the current debate on translation aims and methods, revealing the political and patriotic nature of this activity and its ideological isomorphism with the Pombaline commercial policies.

Keywords: Political Economy; Portugal; Brazil; Colonial Trade; Marquis of Pombal; Enlightened Reforms.

\section{Resumo}

Este artigo oferece um estudo de duas traduções publicadas em 1765-1766 pelo mesmo autor, José Manuel Ribeiro Pereira, um pouco antes de ser nomeado secretário da Junta de Administração da Companhia Geral do Grão Pará e Maranhão, uma das empresas privilegiadas de comércio que tinha sido estabelecida pelo Marquês de Pombal em 1755. Os textos que Pereira traduziu foram Les Aventures de Télémaque, de Fénelon, um romance épico cheio de advertências políticas e econômicas, e Élémens du commerce, de Véron de Forbonnais. Em um país e uma época em que a maioria da discussão sobre economia política era um assunto privado ou da corte, essas traduções contribuíram com o debate público sobre as reformas econômicas introduzidas por Pombal no momento crucial em que, após a Guerra dos Sete Anos (17561763), a aliança reforçada com a Grã-Bretanha e uma mudança significativa em seus interesses comerciais pareciam exigir uma reformulação das estratégias comerciais e industriais portuguesas. A segunda edição das traduções de Télémaque, publicada por Pereira em 1784-1785, fez parte de uma segunda onda de debate público sobre a economia política, dessa vez conectada à questão fundamental do futuro das instituições criadas por Pombal, após sua demissão em 1777. Curiosamente, o paratexto das traduções de Pereira abre uma janela sobre o debate da época sobre os objetivos e métodos de tradução, revelando a natureza política e patriótica dessa atividade e seu isomorfismo ideológico com as políticas comerciais pombalinas.

Palavras-chave: Economia Política; Portugal; Brasil; Comércio Colonial; Marquês de Pombal; Reformas do Iluminismo.

\section{Introdução}

O debate público sobre a economia política no século XVIII em Portugal dificilmente pode ser definido como animado e participativo. A maioria das 
contribuições da época joanina (1706-1750), assim como as de Luís da Cunha, Alexandre de Gusmão e Sebastião José de Carvalho e Melo, o futuro Marquês de Pombal, foram cartas, instruções e pareceres que apenas circulavam em meios oficiais. ${ }^{2}$ A situação não mudou significativamente sob José I, o período caracterizado pela ação de Pombal (1750-1877). Um dos seus mais importantes escritos, apresentando um balanço de sua conduta como Secretário de Estado, foi o Observações Secretíssimas submetido ao rei em $1775 .{ }^{3}$ Uma fonte de informação foi a literatura francesa, britânica e espanhola sobre a economia política que se espalhou entre os intelectuais e os círculos políticos portugueses apesar do filtro da Inquisição e mais tarde da censura Pombalina4. Portanto, as únicas contribuições à discussão pública podem ser consideradas as poucas traduções que foram publicadas após 1750.

A primeira delas em ordem cronológica são os primeiros quatro números de uma publicação periódica de Jacob-Nicolas Moreau (1717-1804), um ex-conselheiro da Cour des Aides de Provença, que em 1774 se tornaria historiógrafo da França e bibliotecário da rainha Maria Antonieta. A publicação em questão é L'observateur hollandez, do qual 47 volumes foram publicados entre 1755 e 1759 . $O$ autor da tradução em português ${ }^{5}$ foi Antonio José de Miranda e Silveira, um bacharel de direito pela Universidade de Coimbra que esteve implicado, alguns anos mais tarde, na tentativa mal sucedida de publicar a tradução de um tratado de gramática francesa, Le mécanique des langues et l'art

\footnotetext{
${ }^{2}$ CASTRO, Armando. As Doutrinas Económicas em Portugal na Expansão e na Decadência (Séculos XVI a XVIII), Lisboa: Instituto de Cultura Portuguesa, 1978, p. 88-117.

${ }^{3}$ Ver: SANTOS, António César de Almeida. “Aritmética Política e governo no reinado de D. José I (Portugal, 1750-1777)", in VI Congresso Internacional de História, 25 a 27 de setembro 2013, http://www.cih.uem.br/ anais/2013/trabalhos/132_trabalho.pdf [accessed on 15th September 2016].

${ }^{4}$ Santos revelou que nos papéis de Pombal de posse da Biblioteca Nacional de Portugal, Lisboa, se encontram os manuscritos de uma tradução em francês de Political Arithmetic [Aritimética Política] de William Petty, e uma tradução em português de An Essay upon Probable Means of Making the People Gainers in the Balance of Trade [Um ensaio sobre os meios prováveis de tornar uma nação lucrativa na balança comercial] de Charles Davenant.

${ }_{5}^{5}$ [MOREAU, Jacques-Nicolas]. o Observador Hollandez ou Primeira Carta de Mons. Van *** a Mons. H. *** de Haya sobre o Estado Presente des Negocios da Europa, traduzida da lingua franzesa na portuguesa por Antonio Joseph de Miranda e Silveira, Lisboa: Officina de Francisco Luis Ameno, 1757; [MOREAU, Jacques-Nicolas]. 0 Observador Hollandez ou Segunda Carta de Mons. Van *** a Mons. H. *** de Haya sobre o Estado Presente des Negocios da Europa, traduzida da lingua franzesa na portuguesa por Antonio Joseph de Miranda e Silveira, Lisboa: Officina de Francisco Luis Ameno, 1758; [MOREAU, Jacques-Nicolas]. o Observador Hollandez ou Terceira Carta de Mons. Van *** a Mons. H. *** de Haya sobre o Estado Presente des Negocios da Europa, traduzida da lingua franzesa na portuguesa por Antonio Joseph de Miranda e Silveira, Lisboa: Officina de Francisco Luis Ameno, 1758; [MOREAU, Jacques-Nicolas]. O Observador Hollandez ou Quarta Carta de Mons. Van *** a Mons. H. ${ }^{* * *}$ de Haya sobre o Estado Presente des Negocios da Europa, traduzida da lingua franzesa na portuguesa por Antonio Joseph de Miranda e Silveira, Lisboa: Officina de Francisco Luis Ameno, 1758.
} 
de les enseigner por Antoine-Noël Pluche (1751), um fracasso no qual a influência de Pombal, que se opunha à discussão livre sobre educação, pode ter sido decisiva. ${ }^{6} L$ 'observateur hollandez era composta de uma série de cartas enviadas por um fictional M. van *** para M.H *** de Haia. Essas cartas criticavam ferozmente a estratégia colonial da Grã-Bretanha e suas tentativas de boicotar o acesso da França aos territórios canadenses. Moreau atacava o governo britânico por suas práticas comerciais e diplomáticas, que sistematicamente violavam os tratados comerciais que a própria Inglaterra tinha aceitado assinar. Sua tradução, que foi dedicada a Pombal, pode ser interpretada como um instrumento de propaganda interna, em uma época em que a Secretaria de Estado do Comércio estava implantando sua política comercial antibritânica. E se a tradução foi interrompida, isso se deu provavelmente por que um trabalho pró-francês e antibritânico como esse se tornaria embaraçoso para o futuro Marquês, exatamente na época em que ele tinha decidido reforçar a aliança entre Portugal e Inglaterra no contexto da Guerra dos Sete Anos (1756-1763).

A segunda tradução foi a de Claude-Jacques Herbert, Essai sur la police générale des grains, sur leurs prix et sur les effets de l'agriculture, ${ }^{7}$ um texto que defendia a retirada das restrições sobre o comércio interno de grãos. Assim como as traduções de Fénelon e Forbonnais que são o foco deste artigo, esse texto pertence ao período crucial dos resultados da Paz de Paris, quando a estratégia colonial e comercial agressiva adotada por Pombal desde 1755 parecia requerer uma revisão sob a luz de mudanças importantes nas alianças de Portugal e seus fluxos comerciais.

A tradução de dois trabalhos pelo político e economista espanhol Pedro Rodríguez de Campomanes ${ }^{8}$ pertence a um período posterior, aquele da ascensão de D. Maria I ao trono e da demissão de Pombal. Campomanes tinha sido nomeado Ministro de Hacienda em 1760 no primeiro gabinete reunido por Carlos III após sua ascensão ao trono da Espanha, e presidido pelo Conde de

\footnotetext{
${ }^{6}$ LUPETTI, Monica. "António José de Miranda e Silveira and the Portuguese Manuscript Translation of NoëlAntoine Pluche's Mécanique des Langues (1766)", paper presented at the LSA Annual Meeting, Washington, DC, 7-10 January 2016.

${ }^{7}$ [HERBERT, Claude-Jacques]. Prova sobre a policia geral dos trigos, sobre os seus preços e sobre os effeitos da agricultura, Bruxellas: por P. de Bast, 1766.

${ }^{8}$ [RODRÍGUEZ CAMPOMANES, Pedro]. Discurso acerca do Modo de Fomentar a Industria do Povo, publicado em Hespanha por ordem de S. Magestade Catholica, e do seu concelho, traduzido em portuguez por Manoel de Sousa, Lisboa: Na Typografia Rollandiana, 1778; [RODRÍGUEZ CAMPOMANES, Pedro]. "Discurso sobre a Educação Popular dos Artistas e seu Fomento, traduzida do Hespanhol por F. R. I. L. E. L. [Francisco Rolland]". Miscelanea Curiosa e Proveitosa: ou Compilação tirada das melhores Obras das Nações Estrangeiras, traduzida e ordenada por ${ }^{* * *}$ C.I., Lisboa: Na Typografia Rollandiana, IV, 1782, p. 132-70, VI, 1784, p. 44-84, VII, 1785, p. 59-148.
} 
Floridablanca. ${ }^{9}$ Os textos que foram traduzidos para o português foram Discurso sobre el fomento de la industria popular (1774), e Discurso sobre la educación popular de los artesanos y su fomento (1775), com seus anexos. Esses textos tinham sido publicados e circulado por todo o país através de uma rede de municipalidades como uma forma de propagar as intenções reformistas do rei Bourbon e seus ministros. Eles examinavam as causas da decadência dos fabricantes espanhóis e propunham uma estratégia intervencionista e protecionista para torná-los prósperos e lucrativos novamente. Eles enfatizavam o papel da educação e da discussão pública como forma de melhorar a produtividade do trabalho e promover um espírito mais empreendedor na população espanhola. Esses discursos foram instrumentais para a instituição, naqueles mesmos anos, das Sociedades Economicas de los Amigos del País, sociedades semi-oficiais de debate que promoviam a discussão e disseminação das ideias econômicas e agronômicas. ${ }^{10}$

Em relação às reformas econômicas, Campomanes foi para a Espanha o que Pombal tinha sido para Portugal, e a tradução de seus discursos no final dos anos 1770 e início dos anos 1780 não fez mais do que revelar uma intenção de enfatizar a continuidade entre as reformas econômicas que tinham sido introduzidas e a arquitetura institucional projetada pelo novo gabinete. Curiosamente, o autor da tradução do Discurso acerca do Modo de Fomentar a Indústria do Povo foi o capitão Manuel de Sousa, um engenheiro do exército real e membro da Arcadia Lusitana, que traduziu Fénelon e Molière e foi provavelmente o autor de um dos primeiros dicionários francês-português, publicado anonimamente em $1769^{11}$. Sousa era amigo do poeta Francisco Manuel do Nascimento, também conhecido sob o apelido acadêmico de Filinto Elisio, e

\footnotetext{
${ }^{9}$ LLOMBART, Vicent. Campomanes, economista y político de Carlos III, Madrid: Alianza Editorial, 1992.

${ }^{10}$ ALMENAR, Salvador and LLOMBART, Vincent. "Spanish Societies, Academies and Economic Debating Societies", in AUGELLO, Massimo M., GUIDI, Marco E.L. (eds), The Spread of Political Economy and the Professionalisation of Economists. Economic Societies in Europe, America and Japan in the Nineteenth Century, London: Routledge, 2001, p. 109-25.

${ }^{11}$ [SOUSA, Manuel de]. Dictionnaire françois, et portugais plus complet que tous ceux qui ont paru jusqu' a present pour l'instruction de la jeunesse portugaise, Lisbonne: Chez Georges Rey, \& Compagnie; Imp. de Michel Manescal da Costa, 1769. 0 título da segunda edição desse dicionário é a fonte sobre a qual a provável atribuição da primeira edição anônima de Sousa se baseia. Ver: MARQUES, A.H. de Oliveira. História de Portugal, Vol. II, Do Renascimento às Revoluções Liberais, Lisboa: Editorial Presença, 1997. De acordo com a informação fornecida por Verdelho, o dicionário de Sousa é o segundo em seu gênero a ter sido publicado em Portugal: VERDELHO, Telmo. "Lexicografia Portuguesa Bilingue. Breve Conspecto Diacrónico". In: VERDELHO, Telmo \& SILVESTRE, João Paulo (eds.), Lexicografia Bilingue. A Tradição Dicionarística Português - Linguas Modernas, Lisboa and Aveiro: Centro de Linguística da Universidade de Lisboa and Universidade de Aveiro, 2011, p. 20-2.
} 
juntos eles planejaram uma tradução de Les Aventures de Télémaque (1770), de Fénelon, que seguiu aquela examinada neste artigo. ${ }^{12}$

o Discurso sobre a Educação Popular dos Artistas e seu Fomento foi publicado em três partes na Miscelanea Curiosa e Proveitosa: ou Compilação tirada das melhores Obras das Nações Estrangeiras. ${ }^{13}$ Seu tradutor foi Francisco Rolland, o empresário que possuia uma das mais ativas casas de impressão em Lisboa, a Typographia Rollandiana. Rolland tinha apenas composto um trabalho lexicográfico intitulado Adagios, proverbios, rifãos e anexins da lingua portugueza tirados dos melhores authores nacionaes, e recopilados por ordem alfabetica (1780), uma coleção que atualizava a que tinha sido publicada no século XVII por António Delicado and Bento Pereira ${ }^{14}$.

Ao mesmo período pertence a última tradução significativa publicada em Portugal no século XVIII, a de Elementos da Policia Geral de hum Estado de Élie Bertrand e Fortunato Bartolomeo De Felice (1786-1787), traduzido do francês por João Rosado de Villalobos e Vasconcellos. Fortunato Bartolomeo De Felice era um italiano que se estabeleceu em Yverdon, na Suíça, como um editor e editou a Encyclopédie ou dictionnaire universel raisonné des connaissances humaines (a assim chamada Encyclopédie d'Yverdon, 1770-1780). Ele também editou e traduziu vários trabalhos filosóficos e legais e editou diversos periódicos literários e científicos, com a intenção de espalhar a ideia do Iluminismo na Itália e na Suíça. ${ }^{15}$ Élie Bertrand (1713-1797), irmão do agrônomo Jean Bertrand (1708-1777), foi um pastor suiço que fundou em 1761 a Société économique d'Yverdon. Eles conjuntamente foram co-autores dos Elémens de la police générale d'un Etat, publicado anonimamente pelo próprio De Felice ${ }^{16}$. O trabalho continha uma descrição dos princípios de arte da "polícia" e uma descrição detalhada da operação dessa instituição na Suíça. ${ }^{17}$ Ela ilustrava as tarefas do governo em uma grande variedade de áreas, desde o

\footnotetext{
${ }^{12}$ SILVA, Inocêncio Francisco da. Diccionario Bibliographico Portuguez, Vol. 6, Lisboa: na Imprensa Nacional, 1862, p. 113-4.

${ }^{13}$ [RODRÍGUEZ CAMPOMANES, Pedro]. "Discurso sobre a Educação Popular ...

${ }^{14} \mathrm{Cfr}$. Corpus Lexicográfico do Português, http://clp.dlc.ua.pt/Corpus/FranciscoRolland.aspx [acessado em 20 Set. 2016].

${ }^{15}$ FERRARI, Stefano. "Le « Tartuffe » et le « coquin »: les rapports intellectuels entre Élie Bertrand et Fortunato Bartolomeo De Felice”, in Le savant médiateur au 18e siècle: science, religion, éducation au sein de l'Etat. A l'occasion du tricentenaire d'Elie Bertrand (1713-1797), Genève: Slatkine, 2017.

${ }^{16}$ Ver: MICHAUD, Louis-Gabriel. Biographie universelle ancienne et moderne, ou histoire, par ordre alphabétique, de la vie publique et privée de tous les hommes qui se sont fait remarquer par leurs écrits, leurs actions, leurs talents, leurs vertus ou leurs crimes, Vol. 13, publié sous la direction de M. Michaud; ouvrage réd. par une société de gens de lettres et de savants, Paris: Madame C. Desplaces et M. Michaud, 1855, p. 493-5, 495. ${ }^{17}$ DENYS, Catherine. Circulations policières: 1750-1914. Presses Univ. Septentrion, 2012, p. 152-60.
} 
encorajamento do espírito marcial, ao controle da moralidade da aristocracia, a manutenção da paz, segurança e saúde pública, a limpeza e iluminação de ruas, e o desenvolvimento da agricultura, indústria e comércio. ${ }^{18} \mathrm{~A}$ tradução em português, que é aparentemente a única a ter sido publicada desse tratado, foi em certo sentido complementar àquela de Campomanes cujo foco era a Espanha, ela abriu uma janela sobre a tradição cameralista do governo para a economia, que tinha sido caracterizada pela área de falantes de alemão no século XVIII. ${ }^{19}$

O tradutor desse tratado foi João Rosado de Villalobos e Vasconcelos, provavelmente nascido em Beja, bacharel pela Universidade de Coimbra, Professor Régio de Retórica e Poética na Universidade de Évora, e em 1782, também em Lisboa, ${ }^{20}$ fundador da Sociedade Patriótica de Évora, baseada no modelo da Société économique de Berna ${ }^{21}$ e membro da Academia dos Obsequiosos, ${ }^{22}$ criada em 1777, o ano da ascensão de D. Maria I ao trono e demissão de Pombal, e presidida por João Dias Talaya Sotomaior. Suas reuniões eram realizadas na quinta da Boavista, em Sacavém, uma propriedade que pertencia a Sotomaior. ${ }^{23}$ Conforme argumentado por Paulo Ferreira, ${ }^{24}$ essa era uma "academia de louvor", criada para bajular a corte em troca de ascensão social. Vasconcelos traduziu diversos trabalhos e foi autor de alguns textos sobre educação que alcançaram certa popularidade.

A tradução foi dedicada ao Intendente Geral da Polícia Diogo Inácio de Pina Manique, um homem de confiança de Pombal, mas indicado para esse papel apenas após sua demissão. $O$ texto principal foi acompanhado de um grande número de notas de rodapé nas quais Vasconcelos ilustra as tarefas e ações da Intendência Geral da Polícia da Corte e do Reino, fundada pelo Marquês em 1760. De acordo com Catherine Denys,${ }^{25}$ o texto precisa ser

\footnotetext{
${ }^{18}$ BARREIROS, Maria Helena. "Urban landscapes: houses, streets and squares of 18th century Lisbon”, in LAITINEN, Riitta, COHEN, Thomas V. (eds), Cultural History of Early Modern European Streets, Leiden-Boston: Brill, 2009.

${ }^{19}$ TRIBE, Keith. Governing Economy: The Reformation of German Economic Discourse, 1750-1840, Cambridge: Cambridge University Press, 1988.

${ }^{20}$ SILVA, Inocêncio Francisco da. Diccionario Bibliographico Portuguez, Vol. 5, Lisboa: na Imprensa Nacional, 1860, p. 30-31.

${ }^{21}$ DENYS, op. cit. p. 152-3.

${ }^{22}$ FERREIRA, Paulo da Costa. As lides do Talaya: Roteiro Biográfico de um Portugal Setecentista, São Paulo: Cascais Editora, 2014, p. 139.

${ }^{23}$ id., p. 137.

${ }^{24}$ id., p. 135.

${ }^{25}$ DENYS, op. cit. p. 152-60.
} 
colocado no contexto de uma avaliação do papel dessa importante instituição Pombalina nos anos iniciais do reinado de D. Maria I. Ele foi outro testemunho de um debate público sobre o legado de Pombal no qual diversas vozes defendem uma continuidade do passado recente ${ }^{26}$.

Este artigo apresenta um estudo de duas traduções portuguesas pertencentes a esse mesmo período: a de Les Aventures de Télémaque, fils d'Ulysse de François Salignac de la Mothe Fénelon (Baseada na edição de 1717), publicada em 1765, e a de Élémens du commerce de Véron de Forbonnais (1754), publicada em $1766^{27}$, dedicada ao Marques de Pombal. Ambas foram feitas pelo mesmo tradutor, José Manuel Ribeiro Pereira. E ambas foram best-sellers (na verdade, Télémaque foi também vendido por muito tempo) em uma escala europeia, tendo sido traduzidos para várias outras línguas europeias e não europeias. ${ }^{28}$ Uma edição recente do Journal of European Ideas ${ }^{29}$ estudou as traduções de Élémens de Forbonnais para o alemão (1762), espanhol (1765), português (1766), e holandês (1779) ${ }^{30}$.



${ }^{28}$ GUIDI, Marco E.L. (ed.). Le avventure delle Aventures. Le traduzioni delle Aventures de Télémaque di Fénelon in Europa tra Sette e Ottocento: saggi bibliografici, Pisa: ETS, 2016.

${ }^{29}$ ALIMENTO, Antonella. "Translation, Reception and Enlightened Reform: The Case of Forbonnais in Eighteenth-Century Political Economy", History of European Ideas, 40, 8, p. 1011-25, 2014.

${ }^{30}$ Ver: CAVARZERE, Marco. “The 'New Science of Commerce' in the Holy Roman Empire: Véron de Forbonnais's Elémens du commerce and its German Readers”, History of European Ideas, 40, 8, p. 1130-50. 2014, sobre a area de falantes de alemão; CARPI, Elena. "The Spanish Translation of the Elémens du Commerce by François Véron Duverger de Forbonnais: A Linguistic Analysis", History of European Ideas, 40, 8, p. 110829. 2014; sobre a Espanha; LUPETTI, Monica, and GUIDI, Marco E. L. "Translation as Import Substitution: 
O que o tão celebrado romance épico de Fénelon e um tratado de comércio saído do círculo de Vincent de Gournay têm em comum, além do seu tradutor? Este estudo oferece uma perspectiva da qual é possível entender sua importância para o discurso público do século XVIII sobre economia política em geral, e especificamente para Portugal no período decorrido entre a indicação de Sebastião José de Carvalho e Melo como secretário de Estado do Reino no início do reinado de D. José I (1750-1777), e os primeiros anos do reinado de D. Maria I, quando Pombal foi demitido. $\mathrm{O}$ artigo revela que tanto as visões econômicas contidas no Télémaque, quanto a abordagem à política de comércio sugerida por Forbonnais, foram revividas e tornaram-se assunto de discussão pública após o final da Guerra dos Sete Anos, oferecendo respostas à crise do comércio português que se desenrolava. Além disso, a segunda edição das Aventuras de Telémaco, publicadas em 1784-1785, lança alguma luz sobre a latitude da preocupação pública sobre o futuro das reformas Pombalinas durante a primeira década do novo reinado.

De certa forma, essas traduções oferecem uma perspectiva da qual pode-se responder a questão que esta introdução apresenta implicitamente: porque as traduções funcionam como um veículo de discussão pública sobre economia política nesses dois períodos? Mas há ainda outra razão de interesse ao examinar as traduções de Ribeiro Pereira: elas originaram um debate interessante sobre os métodos de tradução e a utilidade das traduções, que revela sua natureza política e suas inspirações patrióticas no contexto geral da rivalidade entre as nações e o que David Hume definiu como a "inveja do comércio", ${ }^{31}$ e mais especificamente no cenário das reformas econômicas de Pombal.

Neste artigo nós oferecemos uma reconstrução do perfil do tradutor, uma figura-chave na nomenklatura criada por Pombal para promover suas políticas comercial e colonial e sua estratégia de desenvolvimento da economia portuguesa (item 2). Nós também contextualizamos essas traduções no debate contemporâneo sobre tradução e seus métodos (item 3), e analisamos seu papel na discussão pública do período que se seguiu à Paz de Paris (itens 4 e 5) e a ascensão de D. Maria I ao trono (item 6).

\footnotetext{
The Portuguese Version of Véron de Forbonnais's Elémens du commerce", History of European Ideas, 40, 8: 1151-1188. 2014, sobre Portugal e STAPELBROEK, Koen. "Between Utrecht and the War of the Austrian Succession: The Dutch Translation of the British Merchant of 1728", History of European Ideas, 40, 8, p. 102643, 2014, sobre os Países Baixos.

${ }^{31}$ Ver: HONT, Istvan. Jealousy of Trade. International Competition and the Nation-State in Historical Perspective, Cambridge (MA): Harvard University Press, 2010.
} 


\section{Um tradutor peculiar}

As duas traduções analisadas neste artigo foram produto do mesmo autor, José Manuel Ribeiro Pereira, um bacharel em direito pela Universidade de Coimbra. Nós ignoramos sua data de nascimento, e sabemos bem pouco sobre o início de sua carreira. Apenas sabemos que ele buscava a glória ao publicar durantes três anos consecutivos três traduções dos celebrados textos franceses: de Esprit Fléchier, Oraisons funèbres (publicado originalmente em 1691);32 de François Fénelon, Aventures de Télémaque (de 1699)33; e de Forbonnais, os Élémens... Ao mesmo tempo, ele conseguiu do Desembargo do Paço a qualificação para ocupar um dos "lugares de letras", ou seja, aqueles escritórios legais e administrativos (provedores, corregedores, juízes de fora) em um nível da comunidade local (respectivamente, províncias, comarcas, e conselhos) que diretamente representavam a Coroa ao expandir seu controle sobre a periferia do reino ${ }^{34}$.

Pereira escolheu traduzir esses três textos que poderiam servir suas ambições de acesso à elite política, ao importar para Portugal novas ideias sobre moral, política e economia. No início do século XVIII, a França, juntamente com a Inglaterra, e numa proporção menor a Itália e a Alemanha tinham definitivamente substituído a Espanha como uma influência cultural e política para a elite portuguesa. Além disso, sob o reinado de João V (17061750), e ainda mais decisivamente sob seu sucessor D. José (1750-1777), quando Sebastião José de Carvalho e Melo tornou-se a figura mais influente no governo português, a liderança do movimento reformista foi tomada pelos chamados estrangeirados, que tinham estudado no exterior ou tinham viajado pelas principais capitais europeias como diplomatas ou negociantes, e aspiravam aplicar

\footnotetext{
${ }^{32}$ FLÉCHIER, Valentin-Esprit. Compendio das Orasoens Funebres de Mr Flexier, Bispo de Nymes, vertidas de Fransez em Portuguez, por Jozé Manoel Ribeiro Pereira, bacharel formado na Faculdade de Leis, dadas a Luz por Manoel Rodrigues da Silva, Lisboa: na Ofic. De Antonio Rodrigues Galhardo, 1764.

${ }^{33}$ FÉNELON, François de Salignac de la Mothe. Aventuras de Telemaco, Filho de Ulysses, traduzido do original francez na lingua portugueza, 2 tomos, Lisboa: Na Regia Officina Silviana, e da Academia Real; 1765. 2nd edn/reimp. 1780?. O nome do tradutor não aparece no texto impresso. Entretanto, a autoria de Pereira era conhecida, se alguns anos mais tarde Manuel de Sousa, no prefácio de sua nova tradução de Télémaque (no "Prologo do tradutor" [não numerado]), poderia mencioná-lo explicitamente, e discutir os critérios que tinha adotado para sua tradução. Ver: CRISTOVÃO, Fernando Alves. "Presença de Fénelon no Espaço Literário Luso-Brasileiro. Subsídios para um Estudo". In: Les rapports culturels entre le Portugal et la France, Actes du Colloque, Paris, 11-16 octobre 1982, Paris: Fondation Calouste Gulbenkian - Centre Culturel Portugais, 1983, p. 135-50, 136-7.

${ }^{34}$ Ver: MARQUES, op. cit. p. 312-15; RAMOS, Rui, VASCONCELOS E SOUSA, Bernardo, e MONTEIRO, Nuno Gonçalo, orgs. História de Portugal, 7a edn, Lisboa: A Esfera dos Livros, 2012, p. 401; Arquivo Nacional da Torre do Tombo, Lisboa (doravante ANTT), Companhia Geral de Grão Pará, e Maranhão (doravante Companhia), Livro 87 (Livro de Registo de Consultas), f. 58.
} 
em Portugal as novidades bem-sucedidas que tinham observado por lá. ${ }^{35} \mathrm{Não}$ sabemos ao certo se Pereira tinha vivido na França ou era simplesmente um leitor curioso das principais obras da literatura europeia. Mas suas traduções tinham o objetivo de apresentar a política e cultura francesas como um modelo que Portugal deveria imitar se quisesse se recuperar da decadência e preencher a lacuna que o separava da maioria das mais avançadas monarquias da Europa. Mas - da mesma forma que a maioria de seus contemporâneos - era a França do Grand Siècle que Pereira pretendia disponibilizar aos seus companheiros de pátria, muito mais do que a França do Iluminismo. Dessa forma, Pereira provou-se um astuto observador do clima cultural e político da era de Pombal, e estava muito próximo da estratégia política do então Conde de Oeiras. Como recentemente descrito por Nuno Gonçalo Monteiro:

Pombal, contemporâneo das Luzes, partilhou com elas alguns inimigos - os
Jesuitas e o poder civil da Igreja - e foi buscar nelas alguma influência, não
tanto nas grandes figuras intelectuais francesas do tempo, quanto nas correntes
meridionais que alguns baptizam de "iluminismo católico". Mas não era um
filho das Luzes. Não foi por acaso que ele próprio, tal como o fariam muito dos
seus contemporâneos, se comparou ao Cardeal Richelieu. Em grande medida,
foi um émulo dos ministros/favoritos reformadores do século XVII. E muito
do que fez foi decidido em função das circunstâncias. ${ }^{36}$

A primeira tradução publicada por Pereira foi o Compendio das Orasoens Funebres de Mr Flexier, uma versão simplificada de Oraisons funèbres de Esprit Fléchier. ${ }^{37}$ Conforme observado por Charles-Augustin de Sainte-Beuve no século XIX, Fléchier sofreu na França de uma "comparação exagerada com Bossuet", o grande orador e historiador que tinha sido seu contemporâneo e cujo estilo foi considerado pragmático. ${ }^{38}$ Aparentemente esse não foi o caso em Portugal, onde Fléchier foi não apenas lido e traduzido mais do que Bossuet, mas seu sucesso foi independente de, e em grande parte precedente ao de Bossuet ${ }^{39}$. Entre os tradutores dos trabalhos de Fléchier estava o capitão

\footnotetext{
${ }^{35}$ MARQUES, op. cit. p. $334-8$.

${ }^{36}$ RAMOS et al., op. cit. p. 375.

${ }^{37}$ FLÉCHIER, Valentin-Esprit. Oraisons funèbres composées par M. Fléchier, 2e édition, Paris: A. Dezallier, 1691.

${ }^{38}$ SAINTE-BEUVE, Charles-Augustin. Les Grands écrivains français. Etudes des lundis et portraits classées selon un ordre nouveau, et annotées par Maurice Allem, XVIIe siècle. Ecrivains et orateurs réligieux, Paris: Garnier Frères, 1928, p. 153.

${ }^{39}$ As bibliotecas Portuguesas possuem muitos exemplares das orações de Fléchier e Bossuet (frequentemente publicadas conjuntamente) tanto traduzidas quanto nas versões originais em francês, que mostram que seus trabalhos circularam grandemente pelo país mesmo independentemente das traduções. Para uma lista das traduções portuguesas de Bossuet e Fléchier, ver: LUPETTI e GUIDI, op. cit. p. 1154.
} 
Manuel de Sousa, um engenheiro da Força Armada e membro da Arcadia Lusitana, que traduziu Fénelon e Molière e foi provavelmente o autor de um dos primeiros dicionários francês-português, publicado anonimamente em $1769^{40}$.

A Advertensia não esclarece as razões que fizeram com que Pereira traduzisse as orações de Fléchier. Apenas justifica sua escolha por uma "esperansa de utilidade pública", e ao argumentar que o objetivo do oratório "nam deve ser o lizongear os ouvidos com armoniozos sons, e ocupar a imaginasam com imagens mais brilhantes que solidas; mas sim o comover os corasoens, e intimar a verdade despida de exagerados encomios, e só ornada de pensamentos puros". ${ }^{41}$ Entretanto, as orações de funeral de Fléchier estavam longe de ser um exercício puro de literatura ou meditações religiosas. Elas eram discursos públicos, principalmente devotados aos homens e mulheres que tinham tido papéis chave na vida pública francesa durante o reino de Luis XIV. Em seu Eloge de Fléchier, d'Alembert definiu o grande orador como um "organe de la douleur publique". ${ }^{42}$ Todos os personagens representados soberbamente por Fléchier são 'homens do rei', que trabalham para promover os objetivos do governo: bem-estar, poder militar, justiça, caridade, e ortodoxia religiosa. A principal intenção de Pereira ao publicar essa tradução foi provavelmente política e apologética diante da monarquia portuguesa da época de Pombal. ${ }^{43}$

A primeira tradução foi seguida por dois esforços literários semelhantes; a tradução de Les Aventures de Télemaque, de Fénelon, em 1765, e a de Élémens du commerce, de Forbonnais, em 1766. Dois anos mais tarde, em 5 de março de 1768, José Manuel Ribeiro Pereira foi nomeado secretário da Junta da Administração da Companhia Geral do Grão Pará e Maranhão, uma das empresas de comércio privilegiadas que tinham sido criadas pelo futuro Marquês em 1755 (alguns meses antes do famoso terremoto), para 'nacionalizar' as relações

\footnotetext{
${ }^{40}$ SOUSA, op. cit.; MARQUES, op. cit. p. 338. Esse dicionário não está registrado em VERDELHO op. cit, p. 20-3 entre os primeiros dicionários Português Francês publicados em Portugal na segunda metade do século XVIII. O título da segunda edição desse dicionário é a fonte sobre qual a provável atribuição da primeira edição anônima a Sousa está baseada. De acordo com a informação fornecida por Verdelho, o dicionário de Sousa é o segundo no seu gênero publicado em Portugal. Ver: SOUSA, Manuel de, e SÁ, Joaquim José da Costa e. Nouveau dictionnaire François-Portugais, composé par le capitaine Emmanuel de Sousa, \& mis en ordre, rédigé, revû, corrigé, augmenté, \& enrichi de tous les termes techniques, \& propres des sciences, des arts, des métiers, de géographe; \&c. sur la dernière édition de celui de M. l'Abbé Alberti, \& des tables de l'Encyclopédie, par Joachim Joseph da Costa e Sá..., 2 Vols, Lisbonne: Imp. de Simon Thaddée Ferreira, 1784-1786.

${ }^{41}$ FLÉCHIER... Compendio... p. [1].

${ }^{42}$ D’ALEMBERT... In: FLÉCHIER, Valentin-Esprit. Oraisons funèbres de Fléchier, A Paris: chez Lefèvre, 1826, p. 3. ${ }^{43}$ id., p. 256.
} 
comerciais de Portugal com as colônias do Brasil (a outra era a Companhia Geral de Pernambuco e Paraíba, estabelecida em 1756) ${ }^{44}$. Pereira ocupou o lugar que anteriormente pertenceu a Antonio Domingues do Passo, que tinha se demitido um pouco antes ${ }^{45}$. A nomeação devia ser renovada a cada três anos, e Pereira também deveria fazer o papel de "Juiz de Fora de primeira entrância" para a Companhia ${ }^{46}$. O serviço de Pereira deveria contar como um serviço nos Lugares de Letras (escritório nomeado pelo rei), um papel para o qual, conforme mencionado acima, ele tinha sido qualificado pelo Desembargo do Paço ${ }^{47}$.

A nomeação foi aprovada pelo rei em 17 de março e Pereira tomou posse em 26 de $\operatorname{març0^{48}}$. Um relatório sobre a organização interna da companhia requerido pelo Secretário de Estado em dezembro de 1756, um ano após o estabelecimento da Companhia, descreve em detalhe o papel do Secretário ${ }^{49}$ : A Junta se reunia todos os meses, nas quartas e sextas-feiras, e todos os membros tinham uma obrigação de estar presentes, a ausência era punida com multas apropriadas ${ }^{50}$. O superintendente (provedor) sentava em um lado da mesa e o Secretário sentava-se do lado oposto, enquanto outros conselheiros (deputados) escolhiam livremente seus assentos. Cada decisão era discutida em profundidade, com o objetivo de alcançar unanimidade. 0 voto da maioria era uma exceção ${ }^{51}$, e nesse caso era o secretário que coletava os votos

\footnotetext{
${ }^{44}$ COSTA, Leonor Freire, LAINS, Pedro, e MIRANDA, Susana Münch. História Económica de Portugal, 1143-2010, Lisboa: A Esfera dos Livros, 2011, p. 268-276. Sobre companhias de comércio portuguesas ver: SARAIVA, José Mendes da Cunha. Companhia Geral de Pernambuco e Paraíba, Lisboa: Bertrand, 1941; TRANCOSO, Francisco D. F. C. Os Arquivos das Companhias Gerais do Grão-Pará e Maranhão e de Pernambuco e Paraíba, Lisboa: Edição da Revista "Ocidente", 1947; CARREIRA, António. As Companhias Pombalinas: de Grão-Pará e Maranhão e Pernambuco e Paraíba, Lisboa: Editorial Presença, 1983; CARREIRA, António. A Companhia Geral do Grão-Pará e Maranhão, São Paulo: Ed. Nacional, 1988; MARCOS, Rui de Figueiredo. As Companhias Pombalinas: Contributo para a História das Sociedades por Acções em Portugal, Coimbra: Almedina, 1997.

${ }^{45}$ ANTT, Companhia, Livro 87 (Livro de Registo de Consultas), f. 58 ("Sobre haver S. Mag.de por bem confirmar a nomeaçaõ que a Junta tem feito do Bacharel Joseph Manoel Ribeiro Pereira para Secretario da mesma Junta").

${ }^{46} \mathrm{Ibid}$. Um juiz de fora era um magistrado nomeado pelo rei normalmente para representá-lo nos concelhos, onde um juiz independente era necessário para avaliar controvérsias legais de forma imparcial. A Companhia, como uma jurisdição especial, era provida de tal figura. Um juiz de primeira entrância (ou instância) era um juiz de julgamentos (ou juiz em uma corte de primeira instância).

${ }^{47} \mathrm{Ibid}$.

${ }^{48}$ ANTT, Companhia, Livro 89 (Livro de Registo das Procurações e Provimentos), f. 3V.

${ }^{49}$ ANTT, Companhia, Livro 87 (Livro de Registo de Consultas), ff. 10-14 ("Rezoluçaõ, Belem, 15 de Dezembro de 1756". Pombal solicitou esse relatório para fornecer um modelo para o estabelecimento da Companhia Geral de Agricultura de Vindas do Alto Douro.

${ }^{50}$ Ibid., f. 11 .

${ }^{51}$ Ibid., ff. 11 r.-v.
} 
emitidos pelos conselheiros ${ }^{52}$. 0 provedor e os deputados eram remunerados com uma comissão de $6 \%$ das vendas, enquanto outros empregados, incluindo o secretário, o juiz conservador e o procurador fiscal, recebiam um salário pago trimestralmente ${ }^{53}$. O secretário também presidia o juramento dos novos provedores e deputados ${ }^{54}$.

Os registros da Companhia revelam o papel onipresente de Pereira, que assinava documentos oficiais, contratos, contas, etc. ${ }^{55}$ Ele contribuía com as atividades principais da Companhia, incluindo o fomento da agricultura no norte do Brasil através de crédito e outros meios, a comercialização de produtos coloniais (cacau, café, algodão, arroz e couro), ${ }^{56}$ a venda de produtos portugueses no mercado brasileiro (não apenas vinho, mas uma série de produtos manufaturados ${ }^{57}$, o comércio de escravos entre a costa da Guiné e o Brasil, ${ }^{58}$ e a administração civil e militar dos territórios imperiais. ${ }^{59}$ Pereira teve sua nomeação repetidamente renovada no escritório ${ }^{60}$, até a extinção da Companhia decretada pela rainha Maria I em 1778, logo após sua ascensão e a demissão de Pombal.

Entretanto, mesmo após a extinção da Companhia, Pereira continuou em seu posto para gerenciar essa liquidação (desta forma a Companhia sobreviveu por um bom tempo após a metade do século XIX). No âmbito da chamada viradeira, Dona Maria anulou a política de títulos adotada por Pombal, que os tinha virtualmente suspendido para dar um basta no poder ilimitado da aristocracia. Não apenas ela concedeu ou restaurou em poucos meses um grande número de títulos e ordens de benefício das principais casas aristocráticas, como também estendeu tal honraria a novas categorias. Um desses títulos foi o Habito da Ordem de Christo, que tinha sido previamente reservado a membros da nobreza civil. ${ }^{61}$ Pereira foi um dos que se beneficiaram dessa

\footnotetext{
${ }^{52}$ Ibid., f. 13v.

${ }^{53}$ Ibid., f. 11v.

${ }^{54}$ ANTT, Companhia, Livro 89 (Livro de Registo das Procurações e Provimentos), ff. 4 v.-5 r. (25 Aug. 1768)

${ }^{55}$ Ver: ANTT, Companhia, Livro 89, ff. 4-9; Livro 90 (Livro de Registo de Escrituras), ff. 17-25.; Livro 91 (Registo do Expediente da Contabilidade), f. 5.

${ }^{56}$ COSTA, op. cit. p. 260-1.

${ }^{57}$ Ver: ANTT, Companhia, Copiadores 94-9.

${ }^{58}$ COSTA, op. cit. p. $270-1$.

${ }^{59}$ RAMOS, op. cit. p. 421.

${ }^{60}$ Ver, por exemplo ANTT., Livro 89, f. 10 (5 Aug 1778).

${ }^{61}$ RAMOS... História de Portugal... p. 406.
} 
extensão: em 29 de outubro de 1778 a rainha concedeu-lhe o Habito, com uma pensão vitalícia adicional. ${ }^{62}$

Não sabemos ao certo por quanto tempo Pereira permaneceu nesse ofício. A motivação das menções na mercê era de que se esperava que ele servisse por, pelo menos, os três anos seguintes. De qualquer forma, ele teve mais tempo para dedicar-se às atividades literárias, e uma vez mais ele se dedicou à tradução do francês. Ele traduziu Ecole du monde, ${ }^{63}$ de Eustache Le Noble, um diálogo educacional entre um pai de nome Aristipe e seu jovem filho Timagene, e The Complaint, or Night Thoughts on Life, Death and Immortality ${ }^{64}(\mathrm{~A}$ reclamação, ou Pensamentos noturnos sobre Vida, Morte e Imortalidade) de Edward Young, (que Pereira traduziu do francês) ${ }^{65}$ uma meditação em versos sobre questões morais e religiosas. O livro foi dedicado a "João Carlos de Bragança e Ligne de Sousa Tavares Mascarenhas da Silva, 2.ำ Duque de Lafões, 4. Marquês de Arronches and 8.. Conde de Miranda do Corvo", que desde 1780 tinha sido nomeado presidente perpétuo da recém-fundada Academia Real das Ciências (estabelecida em 1779). Pereira esperava ser nomeado membro da Academia? Foi certamente difícil para ele se tornar um membro ordinário, uma vez que apenas oito estudiosos poderiam ser incluídos em cada uma das três classes (ciências da observação, ciências do cálculo e letras). Mas ele poderia aspirar a uma posição de membro honorário ou supranumerário, ${ }^{66}$ e ele pode ter pensado que suas tentativas literárias seriam suficientes para obter-lhe tal recompensa. Mas ele falhou nessa tentativa. José Manuel Ribeiro Pereira provavelmente morreu em $1797 .{ }^{67}$

\footnotetext{
${ }^{62}$ ANTT, Registro Geral das Mercês, Livro 5, f. 155.

${ }^{63} \mathrm{LE}$ NOBLE, Eustache. L'École du monde, ou Instruction d'un père à un fils, touchant la manière dont il faut vivre dans le monde. Paris, 1694-1695 (as citações são da edição de Paris: chez Martin Jouvenel, Claude Mazzuel et chez l'auteur, 1700); trad. Escola do Mundo ou instrução de um pai a seu filho sobre o modo, por que se deve conduzir no mundo, dividido em diálogos, traduzida em português por José Manuel Ribeiro Pereira, 4 vols, Lisboa: na Officina de Antonio Rodrigues Galhardo, 1780.

${ }^{64} 6$ vols (London, 1742-1745).

${ }^{65}$ Les nuits d'Young, traduites de l'anglois par M. Le Tourneur. Paris, 1769; trad. Noites Selectas de Young, traduzidas do inglês para o português por Joseph Manoel Ribeiro Pereira, bacharel formado na Faculdade de Leis, atualmente empregado no serviço de Sua Magestade Fidelissima na função de Secretario da Companhia do Pará, e Maranhaõ ... tradução estendida com o Poema do Juizo ultimo do mesmo autor. Lisboa, 1782; 2a. ed. Lisboa, 1783; 3ª. Ed. Lisboa, 1787. SILVA... Diccionario, V, 9, tem datas da primeira edição de 1781. Mas não encontramos nenhum vestígio de tal publicação.

${ }^{66}$ Ver: REIS, Fernando. Academia das Ciências de Lisboa, Instituto Camoes, Ciência em Portugal, Personagens e Episódios, 2003, http://cvc.instituto-camoes.pt/ciencia/e31.html [acessado em 15 de março de 2014].

${ }^{67}$ SILVA, Diccionario... p. 9.
} 


\section{Tradução e Patriotismo}

Antes de analisar as traduções de Les Aventures de Télémaque, de Fénelon e de Élémens du commerce, de Forbonnais é importante examinar a abordagem de Pereira à tradução, contextualizando-a no debate português da metade do século XVIII. A discussão mais analítica desse método está contida no prefácio de Pereira à tradução de Fléchier. O contexto da justificativa é fornecido pelo principal objetivo que Pereira atribui ao seu trabalho: "a esperansa de utilitade publica" ${ }^{68}$ Pereira considerava a produção literária, e a tradução, como uma parte de um programa político de reforma. Dentro dessa abordagem, Pereira fornece sua própria explicação dos benefícios do estilo parafrástico:

A vista de tantas maravilhas despertou em mim o dezejo de traduzilas, atendendo
a que pouco importava aver no orbe Literario tão precioza eloquensia àqueles,
que ignorando o idioma Fransez se nam podiam utilizar de suas raridades.
Perplexo no estilo, que seguiria, da traducsam, me resolvi com Horacio a
seguir a parafrastica, de que uzou Cicero nas duas orasoens que traduziu de
Esquino, e Demostenes; desprezando a literal, a que tanto se inclina o vulgo
mais escrupolozo que prudente. ${ }^{69}$

Pereira iguala a tradução literal à fidelidade pedante. É interessante observar que ele baseia sua justificativa em duas fontes clássicas que foram frequentemente citadas nos debates portugueses do século XVIII sobre tradução: uma passagem da Ars Poetica de Horácio, contendo uma recomendação aos tradutores: "Nec verbum verbo curabis reddere fidus / intepres ${ }^{70}$; e na De Optimo Genere Oratorum ${ }^{71}$, de Cicero, na qual o autor se refere às suas próprias traduções de Aeschines e Demosthenes e argumenta que, para ser perfeita uma tradução deve corresponder por um lado às ideias mais do que às palavras do original, e por outro lado aos cânones da elegância da língua alvo. ${ }^{72}$

\footnotetext{
${ }^{68}$ FLECHIÉR... Compendio... p. [1].

${ }^{69} \mathrm{id}$., p. [3-4].

${ }^{70}$ Ver: HORACIO (Quintus Horatius Flaccus). "Ars Poetica liber”. In: The Works of Horace, C. Smart ed., Philadelphia: Joseph Whetham, 1836, p. 133-4; http://www.perseus.tufts.edu/hopper/text?doc=Perseus \%3Atext\%3A1999.02.0065\%3Acard\%3D125).

71 “Converti enim ex Atticis duorum eloquentissimorum nobilissimas orationes inter seque contrarias, Aeschini et Demostheni; nec converti ut interpres, sed ut orator, sententiis isdem et earum formis tamquam figuris, verbis ad nostram consuetudinem aptis" (Cicero 1811). Tradução: "Pois eu traduzi as orações mais ilustres dos dois mais eloquentes oradores de Ática, faladas em oposição uma à outra: Aeschines e Demosthenes. E eu não as traduzi como um intérprete literal, mas como um orador dando a mesma ideia da mesma forma e molde como eram, em palavras que se conformam à nossa maneira". CICERO, Marcus Tullius. "De Optimo Genere Oratorum". In: M. Tulli Ciceronis, Rhetorica, Tomus II. A. S. Wilkins ed., Oxonii: e Typographeo Clarendoniano, 1911, p. 530-1.
}

${ }^{72}$ FLÉCHIER, Compendio, p. [4]. 
Pereira insiste que um trabalho literário eloquente deve ser traduzido em um estilo igualmente eloquente, e isso implica que "variando de lingua, sem que variaze de frases, viria a ser fastidioza leitura o que era antes deleitavel instrucsam, e lucraria por fruto do trabalho o diminuir os creditos do autor, quando só o meu empenho é enobrecerlhe a memoria, e, dilatando-lhe a fama, aumentarlhe a gloria". ${ }^{73}$

Na verdade, nem Horácio nem Cícero definiram seu método preferido de tradução como parafrástico. Pereira provavelmente derivou o termo da categorização de tipos de tradução propostos pelo clérigo e gramático português Amaro de Roboredo na introdução de Porta das Línguas, ${ }^{74}$ uma adaptação de Ianua Linguarum publicada pelos jesuítas irlandeses de Salamanca doze anos antes. Roboredo listou quatro tipos de tradução: literal, que "faze-se de tal maneira ao pé da letra, que toda a frase da língua que traduzimos se observa". O resultado é que "[a]s palavras são Portuguesas, a frase Latina, a tradução absurda". O segundo tipo de tradução é ainda quase que literal, embora leve em consideração o fato de que as sentenças não são construídas da mesma forma em línguas diferentes. Para formular o mesmo conceito, línguas diferentes usam um número diferente de palavras (por exemplo, artigos, preposições) e as colocam em ordem diferente. Ao reestruturar a sentença de acordo com as regras da língua alvo, o leitor pode quase entender seu significado literal. 0 terceiro tipo e a tradução "por cláusulas", na qual cada língua é categorizada de acordo com seus próprios termos e sentenças idiomáticos, e o objetivo é encontrar a concordância entre eles sempre que possível. Esse é o método mais elegante de tradução. Mas requer um conhecimento profundo de ambas as línguas e só pode ser o resultado de um longo processo de educação no qual o professor leva seus alunos a criar cláusulas a partir de sentenças memorizadas e então tentar reformulá-las na língua alvo. Por último vem a tradução parafrástica. De acordo com Roboredo esse é o método mais difícil de tradução, que requer uma proficiência madura no terceiro tipo, "porque respeita somente o conceito do período, quer uses da mesma frase, quer de diversa, ora exclua algumas palavras, ora ajuntes mais”. A tradução parafrástica deve

\footnotetext{
${ }^{73}$ id., p. [4] e [5].

${ }^{74}$ ROBOREDO, Amaro de. Porta das Línguas ou Modo Muito Accommodado para as Entender Publicado Primeiro com a Tradução Espanhola. Agora Acrescentada a Portuguesa com Numeros Interlineaes, pelos quaes Possa Entender sem Mestre Estas Linguas o que não as Sabe, com as Raizes da Latina Mostradas em hum Compendio do Calepino, ou por Melhor do Tesauro, para as que Querem Aprender, e Ensinar Brevemente, e para os Estrangeiros que Desejaõ a Portuguesa e Espanhola, Lisboa: da Officina de Pedro Craesbeek impressor del Rei, 1623, p. 22-5. Ver: LUPETTI, Monica. Dalla Ianua alla Porta. Il metodo di Amaro de Roboredo al crocevia della riflessione linguistica secentesca portoghese ed europea, Pisa: Edizioni ETS, 2010.
} 
ser precisa na sua própria forma, ao esclarecer os conceitos expressos nas sentenças originais, ao invés de modificar arbitrariamente o seu significado. O ponto que Pereira declara ter feito exatamente é esse e nada mais.

Uma ideia semelhante é repetida no prefácio "A Quem Ler" da tradução de Pereira de Télémaque, um trabalho destinado "aos meos patricios que se naõ tiverem applicado ao estudo da lingua Franceza". Alinhado com as diretrizes de Cícero, Pereira apresenta sua tradução como fiel aos conteúdos e eloquência mais do que às palavras do texto original.

Mas, Pereira realmente se ateve aos critérios de tradução parafrástica rigorosa, enunciados por Roboredo? A validade do seu método de tradução foi abertamente desafiada por Manuel de Sousa no prefácio do que, à luz dessa controvérsia, pode ser considerada uma contra-tradução do texto, ${ }^{75}$ feita para reestabelecer o "verdadeiro" jeito português para Fénelon após o esforço infeliz de Pereira. A maior parte do prefácio foi destinada a discutir os métodos de tradução. Sousa diplomaticamente argumentou que o gênio de Pereira estava mais apto à produção original do que à tradução, e esse gênio não lhe permitiu "ligarse ás prizoens de huma rigoroza traducçaõ". Pereira

... despedaçou os grilhoens, e fez em partes mais huma nova composiçaõ, do que huma versaõ fiel, deixando o que lhe pareceo afectado, e accrescentando o que entendeo que a affermoseava, e servia para melhor se entender; a isto chamaraõ os maledicos desfigurar a obra, argumentando da fecundidade do engenho do Traductor pobreza, e falta de propriedade na lingoagem, e que se omittira algumas bellezas, eraõ por serem de tal formosura, e energia que só na lingoa Franceza se mostravaõ com magestade, e até nos lugares que ampliou davaõ por culpada a lingoa de defeituosa, inculta, e sem concisaõ. ${ }^{76}$

Manuel de Sousa emprega a estratégia de atribuir a algumas "línguas maldosas" uma crítica que na verdade ele compartilha: a forma na qual Pereira aplicou o método parafrástico desfigurou o trabalho ao remover suas belezas estilísticas e substituí-las com prolixidade e língua inculta.

Sousa opôs à tradução parafrástica de Pereira uma mais literal. Mas ele mudou a base de emulação como se fosse da reformulação a um novo estilo. A nova tradução que ele ofereceu era alegadamente mais fiel à narração original e objetivava igualar "pela propriedade e elegancia os lugares mais bellos", embora tenha melhorados muitas passagens "pela energia, concisaõ,

${ }^{75}$ FÉNELON, François de Salignac de la Mothe. 0 Telémaco de Monsieur Francisco de Salignac de la Motte Fenelon, Arcebispo, e Duque de Cambraia, traduzido e dedicado ao Ill.mo, e Ex.mo Senhor Marquez Secretario de Estado, Pelo capitaõ Manoel de Sousa, 2 tt., Lisboa: Na Offic. de Miguel Rodrigues, 1770; 2nd edn, Lisboa: $\mathrm{Na}$ Officina de Joaõ Antonio da Silva, 1776.

${ }^{76} \mathrm{id} ., \mathrm{s} . / \mathrm{p}$. 
abundancia e nobreza de termos, e frases". Essa abordagem nos remete a tradução de Roboredo "por cláusulas", também porque ele declarava que as condições de possibilidade dessa melhoria estavam menos na qualidade subjetiva do tradutor do que no grande estoque de "termos, e frases que encontravamos nos Authores que escreveraõ polidamente em Portuguez". ${ }^{77}$ Por esse apelo às glórias da literatura portuguesa, Sousa introduziu um topos que tinha sido canonizado desde o século XVI ${ }^{78}$ como uma consequência da expansão imperial de Portugal: a imposição da língua oficial portuguesa como uma estratégia de consolidar a conquista colonial. ${ }^{79}$ Tanto o Dialogo em Louvor da Nossa Linguagem, de João de Barros,$^{80}$ como o Dialogo em Defensaõ da Língua Portuguesa, sobre a qual tem disputa hum Portugues com hum Castelhano, de Pêro de Magalhães de Gândavo ${ }^{81}$ argumentavam que a superioridade do português sobre o francês deveria ser atribuída ao fato de que a última, "bem que seja muito abundante de termos abstractos, naõ o he nem ainda medianamente provido de palavras energicas, que naõ provém das faculdades". ${ }^{82}$ A prova de tal superioridade do português foi oferecida pela tradução de Sousa, uma vez que "a cada passo nos termos, e frases que parecem mais escabrosas de passar a nossa lingoa, se nos offereciaõ algumas vezes em tanta abundancia frases iguaes, e talvez melhores, que pendiamos indecisos na escolha". ${ }^{83}$ Sousa continuou com esse registro patriótico ao condenar o emprego crescentemente popular de "Gallicismos" nas traduções e textos técnicos. Não apenas os escritores muitas vezes ignoram o significado correto dos empréstimos que adotam, eles também cometem um crime político contra a identidade nacional, a história nacional e a constituição legal e política de Portugal:

... todas as palavras, de que desdenhaõ, saõ aquellas com que se explicaõ os Escriptores que fazem o fundamento da nossa lingoa, as Leis, Ordenaçoens,

\footnotetext{
${ }^{77}$ Ibid.

${ }^{78}$ FERNÁNDEZ SÁNCHEZ, María Manuela, SABIO PINILLA, José Antonio. “El Humanismo renacentista y la traducción en Portugal en los siglos XVI y XVII". In: SABIO PINILLA, José Antonio, \& VALENCIA, Maria Dolores (orgs.). Seis estudios sobre la traducción en los siglos XVI y XVII, Granada: Editorial Comares, 2003, p. 205-42.

${ }^{79}$ LUPETTI, Monica. "Forme testuali e strategie retoriche di elogio della lingua portoghese nei secoli XV e XVI". In: BOILLET, Danielle and GRASSI, Liliana (eds), Forme e occasioni dell'encomio tra Cinquecento e Seicento Formes et occasions de la louange entre XVIe et XVIIe siècles, Lucca: Maria Pacini Fazzi editore, 2011, p. 297-312. ${ }^{80}$ BARROS, João de. Dialogo em Louvor da Nossa Linguagem, lettura critica dell'ed. Del 1540, introduction by Luciana Stegagno Picchio, Modena: Società Tipografica Editrice Modenese - Mucchi, 1959 [1540].

${ }^{81}$ GÂNDAVO, Pêro de Magalhães de. Regras que Ensinam a Maneira de Escrever e a Ortografia da Língua Portuguesa, edição fac-similada, introdução de Maria Leonor de Carvalhão Buescu, Lisboa: Biblioteca Nacional, 1982 [1574].

${ }^{82}$ FÉNELON, .... O Telémaco de Monsieur Francisco... s./p.

${ }^{83}$ id.
} 
Constituçoens, com que nos regemos, e os Alvarás, e Patentes com que o Monarca nos honra, e muitas saõ usadas nas Leis modernas do nosso Soberano, o que faz com que as hajamos de respeito, e em certo modo nos authoriza para podermos usar das outras, pois nos dá a entender, que tanto as naõ regeita que no mesmo usar nos dá abono para as outras..$^{84}$

Também no caso dos neologismos necessariamente criados para reconstruir "o estillo heróico dessa casta de composiçaõ", Sousa tomou o cuidado de "sempre en que tirassem da boa fonte a sua origem, e da mesma d'onde emana nossa lingoa, imitando nisto a todos os bons Escriptores, que por este modo locupletaraõ a sua lingoa, adoptando termos energicos, e significativos que tirassem a sua origem ou de outros termos da mesma lingoa, ou de outra d'onde a sua emanara...". ${ }^{85}$ Como um dos topos dos elogios da língua é que o português é mais antigo porque mais próximo do latim do que o francês, essa passagem implica que o latim foi considerado uma fonte legítima de neologismos em uma estratégia que tinha por objetivo a nacionalização da literatura estrangeira através da tradução ("sempre as derivo d'outras Portuguezas, ou do Latim d'onde emana a nossa lingoa"). ${ }^{86}$ Significativamente, Sousa conclui essa declaração estratégica ao empregar uma metáfora econômica:

Porque, qual he o homem que se agaste se aos seus muitos cabedaes lhe juntar hum amigo boa soma de moeda de Lei? Engeita-la ha ao portador, ou elle hido, arroja-la ha pela janella? Pois nada menos obraõ os que se enjoaõ de ver huma palavra ou antiga, e bem soante, e energica, ou nova vinda da Latina com bom cunho, que nos poupe huma circumlocuçaõ; e o mais he que agasalhaõ com boa sombra huma Franceza, ou Italiana. ${ }^{87}$

A crítica de Manuel de Sousa espelhava a ortodoxia da época em relação a tradução. A interpretação parafrástica não era popular e Pereira parecia estar bem isolado ao menos na abertura que ele defendia. Por exemplo, Inocêncio da Silva escreveu sobre a tradução de Annais, de Tácito por Luís do Couto Félix que "[a] obra, como tradução, vale pouco ou nada. É antes uma estiradíssima paráfrase, em que os períodos curtos e concisos do texto aparecem como que afogados no mar de reflexões e comentários do tradutor" ${ }^{88}$

\footnotetext{
${ }^{84} \mathrm{Ibid}$.

${ }^{85} \mathrm{Ibid}$.

${ }^{86} \mathrm{Ibid}$.

${ }^{87} \mathrm{Ibid}$.

${ }^{88}$ SILVA, Diccionario... p. 281. TACITUS, Cornelius. Tacito Portuguez, ou Traducçam Politica dos tres Primeyros Livros dos Annaes de Cornelio Tacito, Illustrados com Varias Ponderaçoens que Servem à Comprensaõ assim da Historia como da Politica, offerecido à Magestade del-Rey D. Joaõ V Nosso Senhor, por Luis do Couto Feliz. Obra posthuma, dada a luz por Antonio do Couto Castellobranco Filho do Author, Lisboa: Na Officina Real Deslandesiana, 1715.
} 
Entretanto, no "Prólogo a quem quiser ler", Félix apresenta sua tradução de forma mais prudente como "política e não é rigorosa, ou mais filosófica que gramática, em que sempre a razão tinha melhor lugar que a língua". ${ }^{89}$

Mas Félix é provavelmente um dos últimos que opôs tão diretamente a tradução "fiel", "palavra por palavra" como caracterizada por "moléstia" e "infelicidade", "porque a prisão, ou o medo de sair fora das linhas do original, não lhe deixa liberdade para um rasgo". ${ }^{90} \mathrm{Na}$ era Pombalina a criação das academias, a reforma da educação e uma atitude mais filológica estimulou os tradutores a adotar uma metododologia mais rigorosa. ${ }^{91}$ No "Discurso preliminar do tradutor" na primeira das sete traduções de Ars Poetica de Horácio que apareceu em Portugal no século XVIII, ${ }^{92}$ o Oratoriano padre Francisco José Freire, um membro da Arcádia Lusitana sob o nome de Cândido Lusitano, ditou as "Condições precisas para a boa Tradução" 93 . Ele citou as mesmas fontes usadas por Pereira, a passagem de Horácio sobre interpretação em Ars oratoria, De Optimo Genere Oratorum de Cícero, para concluir de forma oposta:

Desta autoridade claramente se colhe que a Tradução, para ser boa, é preciso que conserve com a fidelidade possível todo o carácter e índole do texto, sem que seja necessário mostrar-se de um certo modo supersticioso em copiar o seu painel toque por toque..$^{94}$

\section{As palavras-chave de Freire nesta interpretação foram "Fidelidade" e "Caráter".}

Nós por fidelidade não entendemos o traduzir literalmente; mas sim o exprimir (quanto for possível) sentença por sentença, e figura por figura, não acrescentando cousa que não se leia no original, e não menos tirando ou mutando cousas que nele estejem. ${ }^{95}$

\footnotetext{
${ }^{89}$ FÉLIX, Luís do Couto. "Prólogo a Quem Ler”, in Cornelius Tacitus, Tacito Portuguez, ou Traducçam Politica dos tres Primeyros Livros dos Annaes de Cornelio Tacito ..., Lisboa: Na Officina Real Deslandesiana, 1715; reprinted in SABIO PINILLA, José Antonio, FERNÁNDEZ SÁNCHEZ, María Manuela. O Discurso sobre a Tradução em Portugal. O Proveito, o Ensino e a Crítica. Antologia (c. 1429-1818), Lisboa: Edições Colibri, 1998, p. 82-4, 82. ${ }^{90}$ id., p. 83.

${ }^{91}$ SABIO PINILLA, \& FERNÁNDEZ SÁNCHEZ, op. cit. p. 36-40.

${ }^{92}$ id., p. 38.

${ }^{93}$ Em itálico no original.

${ }^{94}$ FREIRE, Francisco José (Cándido Lusitano). “Discurso preliminar do tradutor”. In: Arte Poetica de Q. Horácio Flacco, Traduzida, e Illustrada em Portuguez por Candido Lusitano, Lisboa: na Officina Patriarcal de Francisco Luiz Ameno; reprinted in SABIO PINILLA, \& FERNÁNDEZ SÁNCHEZ, op. cit. p. 91-9, 92.

${ }^{95} \mathrm{id}$.
} 
É fácil reconhecer nesta passagem uma referência implícita ao método de tradução de Roboredo "por cláusulas", mas também a influência dos humanistas italianos citados nas páginas restantes do prefácio. Em relação ao caráter de uma tradução:

O carácter, ou índole, consiste em saber conservar na Tradução a mesma gala, o mesmo ar, nobreza e afectos com que se exprime o texto, a cuja circumstância propriamente chamavam os antigos Cores. De sorte que, para haver fidelidade, é preciso ciência, e para haver esta índole, é necessário eloquência. ${ }^{96}$

O novo ideal era, portanto, o da fidelidade em oposição à paráfrase ${ }^{97}$, e de uma imitação estética. Fidelidade não significava uma rendição pedantesca ao palavra-por-palavra, mas uma abordagem filológica profundamente baseada na erudição, e na tradução "por cláusulas". Conforme defendido por António Lourenço Caminha no prefácio de sua tradução de Laelius de Amicitia de Cícero, "[s]er Tradutor não é ser Compositor. A versão há-de ser como uma fiel embaixada, aonde o Legado não deve alterar mais do que lhe ordenou o seu Soberano. É um fiel expelho que só copia o objecto tal que ele é em si próprio; ou como, finalmente, uma pintura que se copia de outro quadro". ${ }^{98}$

Outros intérpretes, entretanto, embora compartilhasem do ideal de fidelidade substantiva de Cândido Lusitano, não estavam convencidos de que preservar as "cores" do original fosse o fim maior de uma tradução. Um texto traduzido em português faria mais do que imitar o estilo original: ele positivamente o emulava, graças à variedade superior e elegância do português sobre as outras línguas. Desta forma, como Manuel de Sousa, e mais implicitamente José Manuel Pereira tinham defendido, uma tradução torna-se um ato político de emulação nacional. ${ }^{99}$ No caso de Portugal, parece, entretanto, mais exato falar de uma ‘nacionalização’ de conteúdos alógenos úteis através

\footnotetext{
${ }^{96}$ Ibid.

${ }^{97}$ Ver, por exemplo VILALOBOS E VASCONCELOS, João Rosado de. "Prefação". In: Os Tres Livros das Instituçoens Rhetoricas de M. Fab. Quintiliano Accommodadas aos que se applicaõ ao Estudo da Eloquéncia por Pedro Jozé de Fonseca, Professor Regio de Rhétorica, e de Poetica na Corte de Lisboa..., Coimbra: na Real officina da Universidade; In SABIO PINILLA, \& FERNÁNDEZ SÁNCHEZ, op. cit. p. 130, que opõe a tradução literal “pensamento a pensamento" à paráfrase; e MATA, José António da. 1998 [1783]. “Prólogo". In: Odes do Poeta Q. Horacio Flacco Traduzidas literalmente na Lingua Portugueza..., Lisboa: Na Offic. Patr. de Francisco Luiz Ameno; In SABIO PINILLA, \& FERNÁNDEZ SÁNCHEZ, op. cit. p. 132-4, que curiosamente interpreta a prase de Orácio na Ars Poetica (1-5) com um argumento contra a paráfrase e a mera imitação!

${ }^{98}$ CAMINHA, António Lourenço. "Prólogo". In [Marcus Tullius Cicero], Lelio, ou Dialogo sobre a Amizade Dedicado a Tito Pomponio Attico. Versaõ Portuguesa..., Lisboa: na Of. Patr. De Francisco Luiz Ameno; In SABIO PINILLA, \& FERNÁNDEZ SÁNCHEZ, op. cit. p. 134-7.

${ }^{99}$ REINERT, Sophus. Translating Empire. Emulation and the Origins of Political Economy, Cambridge, MA, and London: Harvard University Press, 2011.
} 
de sua formulação em estilo doméstico que produz um resultado novo, superior de beleza estética e completude linguística. Isso é, por exemplo, o que Custódio José de Oliveira prudentemente afirmou em seu "Prefação" à tradução portuguesa do Tratado do Sublime. Seu texto opunha a "beleza do original" e a "força dos pensamentos" do texto fonte para a pesquisa que o exercício da tradução nos obriga a fazer "para achar frases próprias com que expressemos quanto pensa o mesmo original". ${ }^{100}$ Ao traduzir nós descobrimos "a variedade e abundância" da língua lusitana.

Que melhor educação e cultura do que o trabalho de traduzir e imitar aqueles Escritores que nos podem servir de seguros Mestres, em cujas obras um sólido engenho pode encher a sua alma das virtudes que quer imitar, transportando-se a fazer própria na sua língua a produção dos pensamentos, expressões, frases e teor da obra estranha, com todas as cores, figuras, naturalidade, força, viveza, graça, majestade, que se encontra na língua que traduz, buscando conservar e suster o carácter, harmonia e estilo do seu Autor, sem se encostar a cada uma das palavras para as seguir conforme a sua ordem, o que todavia mostra servidão e esterilidade de genio. Deste modo fica a tradução parecendo não só uma verdadeira cópia do original, mas outro segundo original... ${ }^{101}$

Outro padre Oratoriano, António Joaquim, que compartilhava o ideal de fidelidade de Cândido Lusitano, introduziu mais um argumento a essa discussão: uma língua rica como o português é ideal para tradução, porque requer menos neologismos do que qualquer outra. E aqueles que empregam muitos neologismos o fazem não por causa da pobreza do seu idioma, mas porque eles são simplesmente ignorantes. "Semelhante género de argumento e prova seria muito material, mas se o não fosse, diria eu que a língua Portuguesa era a mais vasta e abundante de todas as de Europa, porque nenhuma tem mais voluminoso Dicionário". 102

Não é de surpreender que em alguns casos o discurso sobre tradução da era Pombalina e nos primeiros anos do reinado da Rainha Maria mudaram do patriotismo imperial à rivalidade político-econômica. $O$ tradutor anônimo da Histoire générale de Portugal de Nicolas de la Clède justificava a tradução

\footnotetext{
${ }_{100}$ OLIVEIRA, Custódio José de. "Prefação". In: Dionysio Longino, Tratado do Sublime, Traduzido da Lingua Grega na Portuguesa por Custodio José de Oliveira, Presbytero Secular do Habito de S. Pedro, e Professor Regio de Grego em Lisboa, Lisboa: Na Regia Officina Typographica, 1771; In SABIO PINILLA, \& FERNÁNDEZ SÁNCHEZ, op. cit. p. 100.

${ }^{101} \mathrm{id} .$, p. 102-3.

${ }^{102}$ JOAQUIM, António. "Prólogo". In: Orações Principaes de M.T. Cicero Traduzidas na Lingua Vulgar, e addicionadas com Notas, e analyses pelo P. Antonio Joaquim da Congregação do Oratório de Lisboa, em beneficio da Mocidade Portugueza, Vol. 1, Lisboa: na Regia Officina Typographica, 1779; In SABIO PINILLA, \& FERNÁNDEZ SÁNCHEZ, op. cit. p. 112.
} 
portuguesa de seu trabalho por duas razões interligadas. Primeiramente, o original tinha se tornado raro no mercado português e era muito caro. Seria um paradoxo para "[t]odo aquele Homem, que por capricho não quiser ostentar desdenhoso desprezo das cousas do seu País", ser obrigado ou a comprar tais cópias caras ou a "revolverem grossos e pesados Volumes, que já custam achar a quem tem a mesma História, que lá escreveu o Autor Francês". Essa tradução oferecida por "muito mais de metade do preço, por que a pagam em Francês", era, portanto, a primeira melhor alternativa ao original. Assim como os produtos oferecidos pelas fábricas nacionais portuguesas, esse livro substituiu a importação do seu original ${ }^{103}$ Mas, diferentemente da maioria deles, era mais barato do que os produtos manufaturados importados e também mais barato do que as alternativas domésticas existentes! Essa é provavelmente a razão pela qual o tradutor anônimo definia seu trabalho como um "presente" dado à nação portuguesa ${ }^{104}$.

A segunda razão que justificava sua tradução era uma preocupação com os efeitos negativos sobre o orgulho nacional de um livro estrangeiro que mostrava em alguns casos uma hostilidade aberta em relação à história portuguesa. A resposta a esse problema estava muito em linha com a atitude de Pereira: a tradução da história de $\mathrm{M}$. de la Clède tinha sido feita consultando a historiografia nacional, "não somente para verificar os factos que escrivia e restituir fielmente os nomes proprios, que sem esta diligência não tornariam facilmente ao seu proprio estado depois de passarem a Francês". ${ }^{105}$ Isso, entretanto não era uma paráfrase: era revisão e adaptação. E o objetivo final era a nacionalização dos conteúdos originais do francês. Dessa forma a tradução de La Clède era um substituto para a importação não apenas em termos materiais e econômicos, mas também em termos culturais.

A defesa de Pereira a abordagem paráfrasica foi mantida em sua última tradução, aquela de Young's Nights [As noites de Young]. Uma resposta a sua crítica está contida no "Discurso preliminar, Que contém um breve extrato da Vida de Young, com algumas reflexões do seu gênio, e das suas Noites, e sobre esta

\footnotetext{
${ }^{103}$ ANÔNIMO "Prólogo do tradutor". In: Historia Geral de Portugal por Mr. de la Clede. Traduzida em Vulgar, e illustrada com muitas Notas Historicas, Geograficas, e Criticas; e com algumas Dissertações singulares, Vol. 1, Lisboa: na Typografia Rollandiana; reprinted In SABIO PINILLA, \& FERNÁNDEZ SÁNCHEZ, op. cit. p. 114.

${ }^{104} \mathrm{~A}$ atividade de traduzir é comparada ao comércio também por BARBOSA, Jerónimo Soares. "Prefação". In: Marcus Fabius Quintilianus, Instituçoens Oratorias..., Coimbra: na Imprensa Real da Universidade, 1788; In: SABIO PINILLA, \& FERNÁNDEZ SÁNCHEZ, op. cit. p. 138, que argumentava que "se o comércio das fazendas é tão vantajoso, e ainda necessário às indigências da vida, o dos conhecimentos não o deve ser menos aos espíritos que sentem a necessidade de instruir-se, e não têm o meio de o fazer, que são as línguas".

${ }^{105} \mathrm{id}$., p. 115.
} 
Tradução", que é, na verdade, uma adaptação do "Discours préliminaire, contenant un abrégé de la vie d'Young; quelques réflexions sur son génie, sur ses nuits et sur cette Traduction, avec une idée de tous ses Ouvrages" de Le Tourneur, prefaciado na edição francesa de 1769 que é a fonte direta da tradução portuguesa. Mais para o final do texto, entretanto, Pereira interpola alguns parágrafos originais nos quais ele discute seus próprios critérios de tradução. Suas intervenções são motivadas por duas razões: evitar a "repetição de ideias" e omitir aquelas passagens "que julguei naõ seriaõ bem acceitas pelos seus assumptos". ${ }^{106} \mathrm{O}$ resultado que ele obteve dessa forma é

...mais huma paraphrasi, que huma traducçaõ, procurando tirar do Young Inglez, e Young Francez, hum Young Portuguez, que podesse agradar á minha Naçaõ, cujo methodo, que sigo nesta versaõ, e nas mais que tenho feito, he nascido da persuasaõ, em que estou, de que assim se deve traduzer Authores de línguas estrangeiras, e muito proncipalmente aquelles, que sendo de superior merecimento pela materia que trataõ, naõ o lograõ igual pelo gosto, e digestaõ com que escrevem. Desta sorte cuido eu que facilmente nos póde ser proprio o bom dos visinhos, deixando-lhe o máo que naõ necessitamos ler, nem conhecer .107

A paráfrase é, portanto, a forma pela qual, de acordo com Pereira, o tradutor pode obter o resultado de transformar os conteúdos superiores de um original escrito em uma língua estrangeira na língua e estilo portugueses, que positivamente melhoram o original. Reformular é a forma verdadeira de nacionalização da literatura estrangeira. Pereira nunca emprega metáforas político-econômicas, mas sua forma de descrever seu método de tradução é claramente isomórfica ao discurso nas políticas comerciais e industriais pombalinas: a literatura útil tem que ser importada como uma matéria prima, mas sua manufatura deve ser inteiramente processada através da língua e estilo portugueses. Há uma dissensão entre os tradutores sobre a forma de alcançar tal objetivo, não sobre o objetivo: tradução é parte da política de substituição da importação de Pombal. Dessa forma a tradução é politicamente legitimada, uma vez que substitui tanto uma importação não controlada de uma literatura estrangeira lida em seu idioma original, e a barbarização do português através de empréstimos inúteis e imperfeitos de outras línguas.

\footnotetext{
${ }^{106}$ YOUNG, Edward. Noites Selectas de Young, traduzidas do inglez em portuguez por Joseph Manoel Ribeiro Pereira, ... traducçaõ augmentada com o Poema do Juizo ultimo do mesmo Author, Lisboa: Na Offic. Patriarc. de Francisco Luiz Ameno; 2nd edn, Lisboa: Na Offic. de Simão Taddeo Ferreira, 1783; 3a edn Lisboa: Na Offic. De Francisco Borges de Sousa, 1787.
}

${ }^{107}$ id., p. xvi. 
Não é surpresa que, na carta dedicatória de sua tradução dos Elémens du Commerce, e como uma conclusão de um elogio às realizações econômicas e culturais de Pombal, Pereira pede ao Secretário de Estado proteção contra as críticas do "estilo paráfrasico":

Espero que V. EXCELLENCIA desculpe os deffeitos que encontrar na traducçaõ, para que esta sua indulgencia sirva da defença contra os que me arguirem o estillo paraphrastico que segui; pareceme que obterei este indulto, quando naõ tem outro fim o meu trabalho, mais que occupar honestamente o tempo, nem outro algum motivo, que o conduzir-me para a fortuna dos meos Patricios, regulado pelas dispoziçoens ajustadissimas, com que V. EXCELLENCIA lhe prepara cada dia novas felicidades. ${ }^{108}$

O estilo parafrástico está ligado com a ideia de uma política da língua, consistindo de um serviço à nação ao traduzir conhecimento útil de uma extração estrangeira em um estilo nacional que não tem rivais no mundo. A utilidade publica está dessa forma conectada ao patriotismo, e a tradução é um feito patriótico.

\section{A primeira tradução de Les Aventures de Télémaque de Fénelon}

A tradução de Pereira de Les Aventures de Télémaque, o romance épico escrito por Fénelon no final do século 17 para instruir o neto de Luis XIV, foi a primeira a ser publicada em Portugal em $1765 .{ }^{109}$ Esse romance foi muito popular não apenas por seus méritos literários, mas também por ter sido extensivamente adotado por preceptores e professores por toda a Europa, como um manual para o ensino do francês e como uma leitura moral recomendada aos descendentes das classes governantes para instilar neles o amor ao heroísmo e virtudes morais e cívicas ${ }^{110}$. Mas sendo originalmente um manual para a educação do príncipe, Télémaque também herdou as características de specula principis, contendo sob o véu da literatura um número considerável de noções políticas e econômicas. Se a tradução portuguesa seguiu por mais

\footnotetext{
${ }_{108}[$ [FORBONNAIS]... Elementos do Comercio... s./p.

${ }^{109}$ LUPETTI, Monica, e GUIDI, Marco E. L. “Le traduzioni lusofone delle Aventures de Télémaque (1765-1915)”, in GUIDI, Marco E.L. (ed.), Le avventure delle Aventures...

${ }^{110}$ Esse papel pedagógico foi bem documentado para Portugal e Brasil respectivamente por SALEMA, Maria José. “Amour et haine: Télémaque et l'apprentissage du français au Portugal”, Documents pour l'histoire du français langue étrangère ou seconde, 31, http;//dhfles.revues.org/1350 [published on 1st Jan. 2012, accessed on 26th Mar. 2014]. e ABREU, Márcia. "The Adventures of Telemachus in the Luso-Brazilian World", in Christoph Schmitt-Maaß, Stefanie Stockhorst and Doohwan Ahn (eds), Fénelon in the Enlightenment: Traditions, Adaptations, and Variations, Amsterdam - New York, NY: Rodopi, 2014, p. 193-209.
} 
de meio século as traduções em inglês, espanhol, italiano e outras línguas, ${ }^{111}$ as razões que tornaram esse texto atraente nos anos que seguiram a Guerra dos Sete Anos (1856-1763) devem ser investigadas com cuidado.

A evidência paratextual não ajuda muito a responder essa questão fundamental. No curto prefácio "A Quem Ler", Pereira apenas argumenta que ele pretendia direcionar esse trabalho "aos meos patricios que se naõ tiverem applicado ao estudo da lingua Franceza”. Mas a mensagem política do romance de Fénelon era muito evidente para passar despercebida. Objetivamente, traduzir Télémaque significou para Pereira apresentar uma ideia de reforma política e econômica para Portugal, baseada no plano proposto por Fénelon através dos modelos de Creta de Minos ${ }^{112}$ e de Salente de Idomeneu, sem esquecer de Tiro, a metrópole de uma nação comercial, sob um rei sábio como Sesostris. É verdade que a pressão da censura que Pombal estava gradualmente introduzindo naqueles mesmos anos tornou prudente apresentar as ideias políticas de forma indireta, como o formato literário de Télémaque o permitiu, ao invés de diretamente através de panfletos ou tratados políticos. ${ }^{113}$

O programa político e econômico contido no romance mais famoso de Fénelon é hoje bem conhecido. Istvan Hont recentemente descreveu o projeto econômico de Fénelon como uma alternativa "compreensiva, grande e virtuosa" embora "tanto difícil quanto arriscada" ao programa imperialista descrito por David Hume através da fórmula da "inveja do comércio". ${ }^{114}$ De acordo com Hont, "A peça central do romance era um ataque visceral ao militarismo de Luís XIV entregue no formato de uma fábula elaborada sobre um reino pacífico". ${ }^{115}$ A política comercial e industrial de Colbert era vista por Fénelon como o lado econômico do militarismo da Coroa Francesa. A política de urbanização acelerada subvertia a ordem natural, causando o declínio da agricultura e consequentemente da principal fonte de impostos, e a redução da população rural, encorajando o luxo e fazendo com que parecesse uma necessidade. A França arriscou do seu modo a mesma decadência experimentada por Roma no passado, porque "o luxo levaria à derrota militar e à revolução doméstica". ${ }^{116}$

\footnotetext{
${ }^{111}$ GUIDI, Le avventure delle Aventures...

${ }^{112}$ FÉNELON, François de Salignac de la Mothe. Les Aventures de Télémaque, chronologie et introduction par Jeanne-Lydie Goré, Paris: Garnier, 1987, p. 194-7.

${ }^{113}$ MARQUES, op. cit. p. 349-51.

${ }^{114}$ HONT, op. cit. p. 26.

${ }^{115}$ id., p. 25.

${ }^{116} \mathrm{id} .$, p. 26.
} 
Mais recentemente, Sophus Reinert, em Translating Empire, generalizou a interpretação de Hont ao descrever a análise econômica contida em Télémaque como a origem de uma tradição de política econômica baseada na agricultura, no livre comércio, pacifista e aristrocrático culminando na Fisiocracia. De acordo com Reinert, o romance de Fénelon foi "realmente uma crítica incisiva à economia política contemporânea e uma corajosa defesa da nobreza tradicional". ${ }^{117}$ A economia política contemporânea era representada pelas políticas de Colbert e pelos autores de panfletos e tratados que engrandeciam as manufaturas e o comércio como a base do poder e bem-estar nacionais. Um deles era John Cary, autor de An Essay on the State of England in Relation to its Trade, its Poor and its Taxes, for carrying out the Present War against France [Um ensaio sobre o Estado da Inglaterra em relação a seu comércio, seus pobres e seus impostos, para continuar com a Guerra atual contra a França]. ${ }^{118} \mathrm{O}$ trabalho de Reinert se concentra nas traduções desse trabalho, que espalhou grandemente a mensagem de Cary por toda a Europa. Portanto, na conclusão de Reinert:

Em um panorama idealizado de economia política, duas tradições estavam
emergindo [...]. Por um lado, havia uma tradição baseada na indústria,
criatividade urbana e capitalismo financeiro fomentada pelos panfleteiros
Guilhermitas como Cary, através de Melon a Diderot e o círculo de Gournay. [...]
Por outro lado, uma corrente profundamente conservadora existia, obcecada
pela agricultura como fonte de melhoria material e moral, que se estendida a
partir de Fénelon até a escola conhecida como Fisiocracia e além". ${ }^{119}$

Agora, havia uma intenção na mente de Pereira de usar sua tradução do romance como uma arma intelectual para intervir no debate sobre o futuro de Portugal após a Paz de Paris?

Uma primeira parte da resposta vem da natureza política e pedagógica do trabalho. As Aventures de Télémaque ofereciam um modelo de monarquia absoluta iluminada, pacífica, hegemônica e paternal ${ }^{120}$ baseada na regra da lei, ${ }^{121}$ e na reforma de uma ordem tradicional social e econômica que objetivava preservar suas hierarquias ao invés de revertê-las. ${ }^{122} \mathrm{~A}$ introdução da

\footnotetext{
${ }^{117}$ REINERT, op. cit. p. 135.

${ }^{118}$ CARY, John. An Essay on the State of England, in relation to its Trade, its Poor, and its Taxes, for Carrying on the Present War against France, Bristoll: Printed for the Author, 1695.

${ }^{119}$ REINERT, op. cit. p. 136.

${ }^{120}$ FÉNELON, op. cit. p. 137-9, 254, 351.

${ }^{121}$ id., p. 196, 205.

${ }^{122}$ GALLOUÉDEC-GENUYS, François. Le Prince selon Fénelon, Paris: Presses Universitaires de France, 1963, p. 186-98.
} 
frugalidade e temperança nos hábitos de todos os súditos, incluindo a corte e sua aristocracia, eram elementos importantes dessa estratégia. O luxo era visto por Fénelon como uma ameaça à estabilidade social, não apenas porque corrompia a moral da população, ${ }^{123}$ mas também porque subvertia as hierarquias sociais ao permitir a burguesia enriquecida e a noblesse de robe a parecer superiores do que a aristocracia mais antiga "da espada". ${ }^{124}$ Tal reforma da moral pública deveria ser promovida através da educação pública, ${ }^{125}$ uma vez que "les enfants [...] appartiennent moins à leurs parents qu'à la république; ils sont les enfants du peuple; ils en sont l'espérance et la force". ${ }^{126}$

Essa ênfase na frugalidade era difícil de aplicar a qualquer sociedade européia do século XVIII, incluindo Portugal, mas a postura política de Fénelon tinha ao menos dois aspectos que espelhavam os princípios políticos das reformas Pombalinas, e que poderiam parecer um elogio à virtude política do Secretário de Estado: a subordinação da aristocracia à coroa, e o papel da educação como uma ferramenta para a reforma da moral e melhoria da formação política e econômica tanto da aristocracia quanto as classes comerciais. A limitação de uma ascendência tradicional dos Grandes tinha como um dos seus alicerces a ação de Pombal desde sua nomeação como Secretário de Estado em 1750, e tinha sido a causa provável de uma tentativa de regicídio em 1758 e o consequente "processo dos Távoras", pelo qual Pombal atribuiu a responsabilidade do ataque a algumas das principais famílias da nobreza e executou seu plano de completa subordinação a ela. Uma das consequências da repressão foi a expulsão dos Jesuítas de Portugal e a reforma da educação, culminando com a criação da Aula de Comércio em 1759 e o estabelecimento do Real Colégio dos Nobres em 1761.

Mas o programa político de Fénelon também implicava uma mudança radical na economia política de um governo virtuoso, bem representado pelas reformas ditadas pelo Mentor a Idomeneu e a partir daquele momento introduzidas em Salente. Essas reformas introduziram leis sumárias e restrições à produção e importação de produtos de luxo. ${ }^{127}$ Preservar as hierarquias sociais também implicava reduzir o espaço para competição e emulação, e esse objetivo poderia ser obtido por uma subdivisão da terra de acordo com a categoria nobiliária, mas evitando a concentração de grandes propriedades em

\footnotetext{
${ }^{123}$ FÉNELON, op. cit. p. 209.

${ }^{124}$ GALLOUÉDEC-GENUYS, op. cit. p. 198-200.

${ }^{125}$ FÉNELON, op. cit. p. 348.

${ }^{126}$ id., p. 381; Ver: GALLOUÉDEC-GENUYS, op. cit. p. 206-10.

${ }^{127} \mathrm{id} .$, p. 200.
} 
poucas mãos. ${ }^{128}$ Também implicava em promover uma população abundante, ${ }^{129}$ uma agricultura estável (e estacionária), ${ }^{130}$ como o crescimento econômico liderado pelo comércio e manufaturas ameaçaria a primazia da aristocracia fundiária. ${ }^{131}$ Fénelon favorecia as pequenas propriedades não como um incentivo à produtividade, mas como uma medida que concedia a cada camponês honesto uma existência modesta, porém segura, saudável e robusta. ${ }^{132} \mathrm{O}$ comércio seria igualmente encorajado desde que fosse baseado na troca de produtos agrícolas e que objetivasse fornecer a nação com meios de subsistência abundantes e de baixo custo. ${ }^{133}$ Encorajar o comércio para promover acúmulo e crescimento não estava contemplado. Mas o comércio não deveria ser estimulado por meios artificiais e em detrimento da agricultura, conforme Colbert tinha tentado fazer. Reis sábios deveriam apenas permitir navios de qualquer país descarregar em seus portos, atraindo através do livre comércio o maior número possível de mercadores. ${ }^{134}$

Essa mensagem anti-Colbertista da economia política de Fénelon foi claramente transmitida pela tradução de Pereira. Por que lhe permitia promover essa ideia no ápice das políticas de Pombal que objetivavam criar as manufaturas reais portuguesas, e proteger o comércio nacional através de leis de navegação e monopólios artificiais sobre o comércio nacional e colonial? ${ }^{135}$ Pereira não estava ciente das diferenças entre o que Fénelon recomendava e o que Pombal estava fazendo? Ele pretendia com isso criticar as políticas do Conde de Oeiras? A resposta a essas perguntas deve levar em consideração dois níveis diferentes na estrutura do discurso econômico de Fénelon. O primeiro e mais abstrato nível era representado pela definição normativa dos objetivos da economia política. Desse ponto de vista Télémaque, também em virtude do seu formato literário e pedagógico, era uma obra de arte da ideologia da monarquia paternal ativamente promovendo o bem-estar, aumento da população, e poder de uma nação pacífica através de uma agricultura próspera

\footnotetext{
${ }^{128}$ id., p. 222-5.

${ }^{129}$ FÉNELON, op. cit. p. 324, 327, 344.

${ }^{130} \mathrm{id}$., p. 209, 324-5.

${ }^{131}$ GALLOUÉDEC-GENUYS, op. cit. p. 215-6.

${ }^{132}$ id., p. 232-3; FÉNELON, op. cit. p. 343, 347.

${ }^{133}$ id., p. 325-6.

${ }^{134}$ GALLOUÉDEC-GENUYS, op. cit. p. 230.

${ }^{135}$ COSTA, op. cit. p. 240-6, 266-76; BIRMIGHAM, David. A Concise History of Portugal, 2nd edn, Cambridge: Cambridge University Press, 2003, p. 67-98.
} 
e um comércio regular. ${ }^{136}$ Além disso, o romance exaltava os benefícios para as nações das reformas iluminadas ditadas pela razão (Mentor, i.e. Minerva) e implantadas por um monarca absoluto sábio.

Num segundo nível, o romance implicitamente recomendava uma estratégia reformista que para Fénelon estava mais adaptada para restaurar a hegemonia da França na Europa após a Guerra dos Nove Anos (1688-1697) concluída com a derrota imposta pela Liga de Augsburgo e o consequente Tratado de Ryswick (1797). A estratégia bélica de Luís XIV parecia ter chegado ao fim, e era hora de redefinir o futuro do país. Fénelon igualava o futuro da França ao reino reformado de Salente sob Idomeneu, "convertido" à paz, agricultura, livre comércio por Mentor, e esse "novo acordo" era apresentado como a causa do novo prestígio e hegemonia adquiridos pelo reino entre as nações vizinhas.

O romance de Fénelon também descrevia sob uma luz favorável o reino pacífico e comercial de Tiro, ${ }^{137}$ um caso por trás do qual os comentadores da época identificaram os Países Baixos daquela época. Conforme sugerido acima, ao traduzir Les Aventures de Télémaque em 1765, Pereira tinha certamente em mente os problemas de Portugal, um país pequeno como o último, com interesses coloniais e comerciais parcialmente semelhantes, que se seguiram ao Tratado de Paris (1763). Politicamente a guerra tinha obrigado Pombal a fortalecer a aliança entre Portugal e a Grã-Bretanha. ${ }^{138}$ Do ponto de vista econômico isso significou que as tentativas iniciais de Pombal de emancipar o comércio português do jugo das companhias comerciais britânicas tiveram de ser reformuladas. Ao mesmo tempo, o fim da guerra produziu uma mudança importante nas relações comerciais entre Portugal e seu principal aliado e parceiro comercial, a Grã-Bretanha. As importações portuguesas, que representavam uma parcela significativa das exportações britânicas na primeira metade do século XVIII, tornaram-se menos importantes com a abertura de mercados novos e mais lucrativos ao interesse comercial britânico. Ao mesmo tempo, os mercadores britânicos localizados em Portugal pareciam estar menos interessados nos comércios tradicionais, como o de vinho do vale de Douro, e dos produtos de "luxo" de consumo da colônia reexportados por Portugal, tais como café, cacau e cana-de-açúcar, para os quais eles começaram

\footnotetext{
${ }^{136}$ GALLOUÉDEC-GENUYS, op. cit. p. 258-9.

${ }^{137}$ FÉNELON, op. cit. p. 163-9.

${ }^{138}$ MARQUES, op. cit. p. 371-2.
} 
a preferir outros itens tais como metais preciosos. ${ }^{139}$ Nessa situação, os pilares principais da política comercial de Pombal começaram a balançar, ou assim parecia a muitos. Esses pilares incluíam a criação de companhias privilegiadas e a atribuição de monopólios comerciais a elas ou para proteger a agricultura portuguesa e colocar o comércio colonial sob controle, e a criação de manufaturas domésticas para substituir a importação dos produtos de luxo.

Em tal contexto, é plausível que Pereira fosse fascinado pela economia política de Salente baseada na agricultura, frugalidade e comércio livre, como uma estratégia defensiva e virtuosa aplicável a Portugal da época. Afinal, ele não estava só ao expressar sua opinião, se apenas alguns anos antes uma postura em favor da agricultura e anti-luxo tivesse sido adotada por outros observadores, incluindo o magistrado José Vaz de Carvalho, o desembargador Manuel de Almeida e Carvalho, e outro desembargador, Nicolau Francisco Xavier da Silva, cujo Discurso político, histórico e jurídico (1749) era uma defesa às leis sumárias. ${ }^{140}$ Vários aspectos dessa abordagem à economia poderiam parecer como uma crítica à política de Pombal. A regulamentação do comércio adotada por Idomeneu, apenas do seu objetivo de evitar a importação de bens de luxo, não objetivava substituir a importação com itens de luxo nacionais, mas sim bani-los. ${ }^{141}$ Além disso, o comércio seria tão livre quanto possível (ou, mais exatamente, as tarifas de importação seriam ou inexistentes ou moderadas, e, em alguns casos, até mesmo substituídas por bônus sobre a importação), ${ }^{142}$ com vistas a encorajar a importação daquelas necessidades que o solo local não podia produzir ${ }^{143}$ e a exportação do excesso interno ${ }^{144}$ dentro de uma divisão natural do trabalho entre as nações. ${ }^{145}$ Finalmente, as regulamentações da agricultura sugeridas por Mentor a Idomeneu continham uma proibição ao consumo de vinho e bebidas alcoólicas. ${ }^{146}$ Mentor recomendava "prendre garde à ne laisser jamais le vin devenir trop commun dans votre royaume. Si on a planté trop de vignes, il faut qu'on les arrache: le vin est la source des plus grands maux parmi les peuples; il cause les maladies, les querelles,

\footnotetext{
${ }^{139}$ COSTA, op. cit. p. 253-6.

${ }^{140}$ CASTRO, op. cit. p. 114-5.

${ }^{141}$ FÉNELON, op. cit. p. 337, 339.

${ }^{142}$ id., p. $326,336$.

${ }^{143}$ id., p. 166-7, 337.

${ }^{144} \mathrm{id}$., p. 269, 336.

${ }^{145}$ GALLOUÉDEC-GENUYS, op. cit. p. 258-9.

${ }^{146}$ FÉNELON, op. cit. p. 195-6, 267-8.
} 
les séditions, l'oisiveté, le dégoût du travail, le désordre des familles". ${ }^{147}$ Alguns anos antes Pombal tinha criado uma companhia - a Companhia das Vinhas do Alto Douro (1756) - para proteger a produção de vinho do Porto e a destilação de aguardente, ${ }^{148}$ e numa situação na qual a exportação desse produto estava ameaçada, a tradução de dita advertência poderia soar como um aviso contra a tentação de promover seu consumo interno. Da mesma forma, se o deficit da balança comercial fosse diminuindo, não haveria necessidade de estimar a produção doméstica de produtos de luxo para substituir os importados, e talvez essa fosse a hora para uma reforma corajosa que restaurasse os valores rurais e as virtudes frugais. Em relação aos itens que não podiam ser facilmente produzidos no solo português, não haveria necessidade de restringir o comércio: abrir os portos ao livre comércio poderia ser uma política atraente para garantir a provisão e preços baixos. Em uma palavra, o plano de Fénelon de "agricultura, frugalidade e comércio livre" poderia ter sido fascinante na conjuntura incerta da metade dos anos 1760.

Mas havia uma ironia nessa história: nenhum dos censores cobrados para avaliar a tradução percebeu as contradições, nem o frei Joaõ Baptista de São Caetano ${ }^{149}$, que atuou como censor da Inquisição (Santo Oficio), nem o frei Joseph da Madre de Deus, censor episcopal (do Ordinário). Mas, foi o censor real (do Desembargo do Paço), Manuel de Macedo Pereira de Vasconcelos ${ }^{150}$, que surpreendentemente argumentou que o serviço principal prestado por Pereira foi publicar opiniões que poderiam confirmar a sapiência e cuidado paternal do rei de Portugal ${ }^{151}$, e apresentar um ponto de vista sobre

\footnotetext{
${ }^{147}$ id., p. 347-8.

${ }^{148}$ COSTA, op. cit. p. 228-9.

${ }^{149}$ Frei Joaõ Baptista de São Caetano era um monge iluminista da ordem de São Bento que promoveu ativamente a importação da filosofia e teologia francesa e italiana contemporâneas (ver: RAMOS, Luís A. de Oliveira. "Pombal e a Reforma dos Estudios Monásticos (o Caso Beneditino)", Revista de História das Ideias, IV, 2: 113-124. 1982).

${ }^{150}$ Ele provavelmente foi um ex padre Oratoriano que em 1760 ou 1761 tornou-se um padre secular e ensinou Retórica e Poesia no hospício de Nossa Senhora das Necessidades em Lisboa. Ver: TOPA, Francisco. "Seis Poemas Inéditos do Brasileiro Manuel de Macedo Pereira de Vasconcelos", Revista da Faculdade de Letras - Línguas e Literaturas, 2a série, XXI: 303-313, 2004; e SILVA, op. cit.

151 "Como he possivel que Vossa Magestade negue a hum livro a licensa que pede para se imprimir, se a moral, que ensina, se as maximas, que establece sam totalmente conformes aos sabios dictames que Vossa Magestade pratîca no seu felicissimo governo? Minerva disfarsada na figura do velho Mentor toma á sua conta instruir ao filho de Ulysses na grande arte de reinar. He com a assistencia particular daquella Deoza que Telemaco, superior á sua idade tenra, se monstra sempre, intrepido nos perigos, constante nos trabalhos, zeloso, e exacto na fiel administraçaõ da justiça, próvido, diligente, incansavel. Como se nascer unicamente para o bem dos povos, de que havia ser pay carinhozo, mais que Monarca absoluto, consagra todos os preciozos momentos da sua vida á utilidade publica." (FÉNELON, Aventuras de Telemaco, s./p.].
} 
a economia política que era exatamente espelhado nas realizações de D. José (e implicitamente de Pombal):

Sim, Senhor, he do juizo delicado de Vossa Magestade, como do cerebro de Minerva, que perennemente dimmanam as meravilhozas rezoluçoens, com que a destra, e infatigavel mam de Vossa Magestade, mam verdadeiramente real, arranca os abuzos mais inveterados, prommove a reforma dos estudos, adianta o commercio, faz florecer as fabricas mais uteis, conserva, e aperfeiçoa a disciplina militar das Tropas ... honra o merecimento aonde quer que o acha, naõ apparente, mas o solido. Feliz Portugal!. ${ }^{152}$

As implicações retóricas destes textos e sua extensão incomum revelam que Vasconcelos não era desconhecedor dos riscos de publicar tal texto. Seu objetivo era mostrar que, apesar das diferenças na abordagem do que era prudente passar sob silêncio, o espírito de fomento era o mesmo para ambos Mentor e Pombal.

Significativamente, a segunda tradução de Télémaque, publicada por Manuel de Sousa em 1770, foi dedicada "ao Ill. ${ }^{\text {mo }}, e$ Ex. ${ }^{\text {mo }}$ Senhor Marquez Secretario de Estado", no mesmo ano em que Pombal obteve o título pelo qual ele é universalmente conhecido. Sousa adotou uma estratégia argumentativa semelhante ao afirmar que Télémaque era "huma obra, cujas maximas sem precisar estudalas, descubrio V. EXCELLENCIA á força de aturada meditaçaõ, poz em pratica desde o berço a sua bem formada indole, e confirmou depois o seu acertado raciocinio". ${ }^{153}$

\section{Os Elementos do Comércio}

A terceira tradução publicada por Pereira em 1766 apresentava ao público português uma adaptação de Elémens du commerce de Forbonnais. O texto era precedido por uma carta dedicatória "Ao ILL. ${ }^{\text {MO }}$ e EX. ${ }^{\text {MO }}$ SENHOR SEBASTIAÕ JOZE' DE CARVALHO, E MELLO Conde, e Senhor de Oueiras, Ministro, e Secretario de Estado de sua Magestade Fidelissima \&c. \&c. \&c.", na qual Pereira se define "hum homem [...] muito amante das fortunas da sua Patria”. ${ }^{154}$ A tradução, nós sabemos, é um ato patriótico, e patriotismo, para Pereira, requeria endossar os esforços extraordinários feitos pelo conde de Oeiras para estimular o comércio Português. A dedicação propositadamente

\footnotetext{
${ }^{152}$ FÉNELON, Aventuras de Telemaco, s./p.

${ }^{153}$ FÉNELON, O Telémaco de Monsieur...

${ }^{154}$ FORBONNAIS... Elementos p. [9].
} 
fornece uma imagem informada e precisa das ações de Pombal onze anos após sua ascensão à liderança no reinado de D. José:

Deve de justiça dedicar-se a V. EXCELLENCIA, hum tratado, que estabelece principios ao Commercio, e augmentos á felicidade publica; pois o Commercio nestes Reinos deve a V. EXCELLENCIA a protecçaõ, e a felicidade publica sempre lhe deverá agradecimentos.

E na verdade, Senhor, naõ he V. EXCELLENCIA aquelle incomparavel Eroé, que sabiamente illustra as maximas mercantís deste escritor preclaro, e que as sabe fazer praticar, e proporcionar igualmente que elle as soube escrever? Naõ he ao zello incansavel de V. EXCELLENCIA, que esta Monarchia venturoza deve os augmentos que consegue, e os progressos com que se vai distinguindo entre as naçoens? Que vantajes naõ estaõ respirando as Fabricas, a Agricultura, e o Commercio? Que abundantes felicidades naõ estaõ prometendo a nossos compatriotas, as altas idéas que para bem universal do Reino, continuamente occupaõ a illuminada comprençaõ de V. EXCELLENCIA.

Por maons de V. EXCELLENCIA, he que o nosso AUGUSTISSIMO MONARCHA dirige aquellas sabias determinaçoens, que saõ a fonte de toda a ventura que logramos. Huma lei que erige Fabricas; outra que anima os artistas com privillegios. Huma que protege companhias mercantís; outra que estabelece juntas que derijaõ regularmente o Commercio, e o bem commum dos vassallos. Huma que funda aulas para a mocidade o aprender; outra que edifica collegios para a nobreza se instruir. Huma que prescreve formas á navegaçaõ; outra que arranca os abusos da Agricultura. Aquella que seguindo os dictames puros da razaõ, poem n'huma ordem seria as ultimas dispoziçoens da vida; esta que attendendo á maior oppolencia do Estado, faz aparecer de novo no Commercio hum bem consideravel fundo de riqueza capaz de girar nelle como moeda... ${ }^{155}$

O tratado de Forbonnais, que parcialmente se originou de um artigo que ele tinha escrito alguns anos antes para a Encyclopédie, atraiu Pereira por causa da fundação 'científica' que Forbonnais declarou ter dado ao estudo do comércio. ${ }^{156}$ Mas era verdade que esse texto confirmava a validade das políticas comerciais Pombalinas? Ou ele era apenas atraente porque clamava por uma reformulação de alguns de seus pilares mais característicos?

Forbonnais baseou sua análise na suposição de que o comércio tinha se tornado nos tempos modernos "la base des intérêts politiques \& de l'équilibre des puissances", 157 porque fornecia um "corpo de política" com a força necessária para manter a estabilidade política e defender-se de seus inimigos internos e externos. Essa força derivava de uma população abundante, atraída pelas

\footnotetext{
${ }^{155}$ id., p. [6-9].

${ }^{156}$ [FORBONNAIS, François Véron Duverger de]. Élémens du commerce. À Leyde, et se trouve à Paris: chez Briasson, David l'ainé, Le Breton et Durand, 1754, p. 42.

${ }^{157}$ id., p. 41.
} 
"riquezas políticas" que um poder comercial saudável poderia oferecer. Essas riquezas políticas consistiam de dois tipos de riqueza: "riquezas reais", isto é, independência de outros países para as necessidades básicas e um grande excesso de produtos manufaturados para exportação, e "riquezas relativas", isto é, o montante de "riquezas de convenção" (dinheiro) que um país era capaz de atrair do exterior, comparado com o dinheiro atraído por países rivais. ${ }^{158}$ Alcançar tal objetivo era o resultado da mão visível de um legislador sábio, e o que constituía "l'art \& la science de l'administration du Commerce politique". ${ }^{159}$ Havia um tipo de comércio que era útil ao corpo político e outro que não o era. O comércio era nocivo quando ele introduzia no país "des marchandises étrangères qui nuisent à la consommation des manufactures nationales". ${ }^{160}$ Os nove princípios da política comercial anunciada por "autores Britânicos" eram totalmente endossados por Forbonnais. ${ }^{161}$ Esses princípios eram constituídos da doutrina tradicional da balança comercial ${ }^{162}$ : minimizar a importação e maximizar a exportação como meio de promover a agricultura e as fábricas nacionais, oferecer emprego a uma população crescente ${ }^{163}$ e aumentar as taxas de juros. Como um admirador de Colbert, ${ }^{164}$ Forbonnais favorecia a produção de produtos de luxo, que tanto poderiam ser consumidos domesticamente como exportados, embora ele argumentasse que um desenvolvimento equilibrado implicaria na promoção contemporânea da agricultura e da indústria. ${ }^{165}$ A defesa de Forbonnais da livre competição ${ }^{166}$ fazia parte de uma política comercial agressiva que objetivava maximizar o excesso da balança comercial geral. ${ }^{167}$ A competição doméstica, juntamente com a mão de obra barata ("oeconomie du travail des hommes"), e com baixo custo de transporte e taxas de juros mais baixas, era uma forma de assegurar a competitividade da exportação nacional. ${ }^{168}$ Mas restrições à liberdade de promover esses objetivos eram também uma necessidade, enquanto que uma competição totalmente

\footnotetext{
${ }^{158}$ id., p. 46-7.

${ }^{159}$ id., p. 47.

${ }^{160} \mathrm{id}$., p. 48.

${ }^{161} \mathrm{id}$., p. $51-2$.

${ }^{162}$ id., p. 72-8, 244-76.

${ }^{163}$ id., p. 54.

${ }^{164}$ id., p. 40-1.

${ }^{165} \mathrm{id}$., p. $55-8$.

${ }^{166}$ id., p. 88-96.

${ }^{167}$ id., p. 80 .

${ }^{168}$ id., p. 62.
} 
livre que trouxesse prejuízos ao corpo político era considerada uma concessão mais do que uma liberdade. ${ }^{169}$

Entretanto, conforme Antonella Alimento observou, Forbonnais era favorável a uma estratégia resumida pela díade 'liberdade e concorrência', que se opunha a estratégia de 'liberdade e protecionismo' apadrinhada pelo Abbé de Gournay, de cujo círculo Forbonnais era um membro ativo. ${ }^{170}$ Gournay e Forbonnais concordavam com a opinião de que desde a era de Luís XIV, a França tinha se concentrado muito em preservar sua força 'na terra', isto é, o teatro Europeu, negligenciando seu papel 'no mar', isto é, como um poder comercial e colonial, para vantagem daqueles, como a Grã-Bretanha e os Países Baixos, que tinham aumentado enormemente sua riqueza e poder nessa área. Mas Gournay tinha argumentado que para competir com tais nações comerciais a França devia imitar a Inglaterra, promovendo o comércio livre dentro do país e ao mesmo tempo adotando uma política agressiva e protecionista com seus rivais externos. A Lei de Navegação de 1651 e a criação das companhias comerciais privilegiadas eram na opinião de Gournay as pedras fundamentais do sucesso inglês que a França deveria copiar. No contexto da Guerra dos Sete Anos, entretanto, Forbonnais acreditava que o protecionismo não auxiliaria um reinado como o da França competir com seus principais rivais. Ao contrário, a França tinha que promover a competição das companhias de navegação rivais para lucrar com a resultante redução dos custos de transporte para seus produtos ao restante da Europa.

Essa estratégia foi claramente descrita por Forbonnais nos capítulos 5 e 6 de Élémens du commerce, respectivamente devotados à navegação e às colônias. Forbonnais admitia que "[t]oute nation qui laisse faire par d'autres une navigation qu'elle pourroit elle-même entreprendre, diminue d'autant ses force réelles \& relatives en faveur de ses rivales", ${ }^{171}$ e que a condição para uma nação que confia seu comércio a companhias comerciais estrangeiras é "la plus facheuse qu'on puisse imaginer, [por que] les intérêts politiques du peuple dépendant seront subordonnés par le besoin, aux intérêts politiques du peuple navigateur". ${ }^{172}$ Ele concordava com Gournay que contrastar esse risco era o objetivo "du fameux acte

\footnotetext{
${ }^{169}$ id., p. 79.

${ }^{170}$ ALIMENTO, op. cit.; ALIMENTO, Antonella. "La concurrence comme politique moderne. La contribution de l'école de Gournay à la naissance d'une sphère publique dans la France des années 1750-1760”, in Jesús Astigarraga and Javier Usoz (eds), L'économie politique et la sphère publique dans le débaat des Lumières, Madrid: Casa de Velázquez, 2013, p. 213-28.
}

171 [FORBONNAIS]... Élémens... p. 317.

${ }^{172}$ id., p. 323. 
de navigation des Anglois, auquel ils doivent l'étendue de leur commerce \& de leur marine". ${ }^{173}$ Entretanto, era também sua opinião que era impossível copiar a Inglaterra nesse assunto. E ele concluiu que "Le seul moyen de se soustraire à la supériorité des navigateurs étrangers, c'est d'établir la plus grande concurrence possible dans sa navigation". ${ }^{174}$

Em relação às colônias, as nações mais inteligentes as tinham reunido em uma área econômica integrada com seu país-mãe, permitindo-lhes as mesmas restrições comerciais que lhe beneficiavam. ${ }^{175}$ Após enumerar as vantagens das colônias para os países europeus, ${ }^{176}$ Forbonnais afirmava que dois tipos de restrições deveriam ser aplicados ao seu comércio: 1. Elas não podem produzir os mesmos produtos produzidos no país-mãe; 2. "Les colonies ne peuvent sans crime consommer les denrées étrangères, dont la métropole consent de leur fournir l'équivalent; ni vendre aux étrangers celles de leur denrées que la métropole consent de recevoir dans ses ports". ${ }^{177}$ Se por um lado as economias coloniais deveriam produzir exclusivamente matéria prima, ${ }^{178}$ isso não significava que os produtos básicos da colônia deveriam apenas ser exportados pelas companhias de navegação nacionais: sobre esse assunto. Élémens du commerce continha uma afirmação forte contra as companhias privilegiadas:

Le grand ressort de cette culture, est le commerce, \& le commerce n'a d'activité que par la concurrence des négocians. Leur ambition fournira toûjours plus d'avances aux habitans cultivateurs, \& fera mieux valoir leurs denrées qu'une compagnie exclusive maîtresse dès-lors du prix des ventes, des achats, du terme des payemens, sans compter les vexations \& les maneges odieux que les commis de ces compagnies ne manquent pas d'employer à leur insçu. Aucune colonie de culture n'a encore réussi, \& ne réussira jamais dans de pareilles entraves. ${ }^{179}$

Em relação ao comércio de escravos, Forbonnais defendia que "[l]e commerce des Negres doit être regardé, favorisé, \& soutenu, comme la base de la culture des colonies". ${ }^{180}$ Mas uma vez mais, seu fornecimento estava melhor servido por "la plus grande concurrence possible entre les négocians", desde que a competição fosse leal. Mas o montante de dinheiro investido na compra de escravos era

\footnotetext{
${ }^{173} \mathrm{id} .$, p. 324-5.

${ }^{174}$ id., p. 326.

${ }^{175}$ id., p. 346-7.

${ }^{176}$ id., p. 371.

${ }^{177} \mathrm{id} .$, p. 372.

${ }^{178} \mathrm{id}$., p. 373-4.

${ }^{179}$ id., p. 382.

${ }^{180} \mathrm{id} .$, p. 383.
} 
muito alto, especialmente no início das plantações, e consequentemente o preço dos produtos coloniais poderia subir significativamente se comparado aos indicadores internacionais. ${ }^{181}$ Sabendo disso, "l'amour, la sagesse, \&l'habileté de la métropole" 182 exigiu a aplicação de proteção temporária, teoricamente baseada em um argumento peculiar de indústria nascente. A seguinte cadeia silogística indicava a reação positiva gerada pelo protecionismo:

L'abondance des consommations est l'unique moyen de rendre la culture lucrative; de son bénéfice naît la concurrence des cultivateurs; de la concurrence, le bas prix de la denrée; du bas prix de la denrée, la supériorité dans cette branche de commerce. ${ }^{183}$

Mas a reação positiva era produto da intervenção inicial: "Pour procurer à la culture lors même qu'elle est chère l'abondance des consommations, la métropole épargne chez elle aux denrées de ses colonies la concurrence des denrées étrangères de la même nature"184. Forbonnais argumentava que as proibições e custos de importação não eram a melhor forma de lidar com essa questão, uma vez que encorajavam contrabando ${ }^{185}$ e retaliação. A melhor vantagem era um bônus sobre as exportações coloniais para o país-mãe ("une gratification qui mette les négocians en état de les vendre à plus bas prix que celles de l'étranger"). ${ }^{186}$ Tais bônus seriam apenas temporários: "Les nations intelligentes dans le commerce s'en tiennent donc aux gratifications jusqu'à ce que la culture puisse s'en passer". ${ }^{187}$ Por sua vez, sua justificativa estava baseada em um entendimento claro da grande elasticidade da demanda de produtos coloniais tais como café, cacau e açúcar, gerada pela competição de poderes coloniais rivais no mercado europeu:

Les étrangers auxquels la métropole réexporte les denrées de ses colonies, les regardent toûjours comme un superflu, \& ne se déterminent pas aisément à y mettre une

\footnotetext{
${ }^{181}$ id., p. 385-6.

${ }^{182} \mathrm{id}$., p. 386.

${ }^{183} \mathrm{Ibid}$.

${ }^{184} \mathrm{O}$ argumento da indústria nascente estava ainda mais claro na seguinte passagem: “Ce n'est pas à sa propre consommation que la métropole doit borner ses vûes: ses secours sont indispensables jusqu'à ce que la consommation extérieure soit bien établie. Elle le sera par l'intérêt qu'auront les étrangers de lui donner la préférence; c'est-à-dire par le bas prix" (id., p. 388-9).

${ }^{185} \mathrm{~A}$ explicação do contrabando é de certa forma interessante baseada na análise de custo-benefício aplicada ao crime, de forma que antecipa Beccaria e Bentham: “...la contrebande se fait par-tout où elle présente un profit excédant son risque; \& ce risque ne consiste pas tant dans la punition que dans les moyens d'éluder les recherches" (id., p. 387).

${ }^{186} \mathrm{id}$., p. 387.

${ }^{187}$ id., p. 387-8.
} 
augmentation de valeur: ou pour parler plus exactement, c'est le consommateur d'une denrée de luxe qui est l'arbitre de son prix. ${ }^{188}$

A causação cumulativa também agiu na direção oposta. Se o preço dos produtos coloniais permanecesse alto na ausência de protecionismo, os competidores estrangeiros seriam encorajados a entrar naqueles ramos de comércio, sua competição reduziria os preços e permanentemente levaria a colônia não protegida a sair do mercado: "il renonce à ce genre de commerce dont ses rivaux s'emparent pour toûjours". ${ }^{189}$

É plausível que a decisão de Pereira de traduzir esse trabalho em 1766 - e não podemos nunca nos esquecer que isso foi feito com a aprovação da censura e após isso do próprio Pombal - foi uma consequência direta de um desejo de apresentar o argumento de "liberdade e concorrência" como uma estratégia para a defesa e promoção do comércio colonial português após a Paz de Paris que colocou um final na Guerra dos Sete Anos. Conforme descrito acima, as consequências políticas e comerciais do final da guerra tinham sido dramáticas para Portugal, fortalecendo a aliança entre Portugal e Inglaterra e questionando os esforços iniciais de Pombal de emancipar o comércio português do controle Britânico. Ao mesmo tempo, as relações comerciais entre esses dois países ameaçavam os setores exportadores tradicionais da economia colonial e interna do império português. Em tal contexto, a estratégia que consistia em reduzir o preço dos produtos brasileiros através dos bônus e concorrência poderia parecer mais atraente a Pereira, adaptada à situação portuguesa e tecnicamente mais sofisticada do que o plano de Fénelon "agricultura, frugalidade e livre comércio". Mas, ele estava pronto a endossar os argumentos de Forbonnais sobre questões tão delicadas como a Lei de Navegação, companhias privilegiadas e o comércio de escravos, sabendo que esses tinham sido os pilares da ação de Pombal na primeira década de sua atividade como Secretário de Estado do Comércio?

A tradução parafrástica serviu muito bem à intenção de Pereira, que pode ser descrita como no mínimo ambígua e oscilante. Por um lado, sua tradução era suficientemente fiel à doutrina de Forbonnais em relação ao livre comércio interno e a promoção do interesse nacional através da competição entre companhias de navegação rivais. Houve, porém, algumas ambiguidades que podem ser interpretadas tanto como tentativas intencionais de moderar os aspectos mais inovadores de Forbonnais, ou como simples inépcia. Por

\footnotetext{
${ }^{188}$ id., p. 390.

${ }^{189} \mathrm{id} .$, p. 392.
} 
exemplo, a passagem crucial na qual o autor francês enunciou sua estratégia foi traduzida com um pouco mais ou menos de liberdades intencionais:

Aujourd'hui tous les peuples sont tropéclairés sur les intérêts du commerce, pour qu'un d'entr'eux osât entreprendre une opération si vigoureuse; il ne seroit pas plus prudent d'imposer des droit sur les vaisseaux étrangers, ni d'augmenter ceux qu'on \| perçoit à l'exportation ou à l'importation sur ces mêmes vaisseaux. Mais il est un autre expédient plus doux \& d'un effet plus certain [...].

Le seul moyen de se soustraire à la supériorité des navigateurs étrangers, c'est d'établir la plus grande concurrence possible dans sa navigation. ${ }^{190}$
Já hoje todos os povos tem suas vistas politicas sobre os interesses do seu commercio, para que nenhum delles se rezolvesse a intentar huma taõ vigoroza operaçaõ. Naõ será com tudo acertado effeito de huma boa politica o impor direitos sobre os navios estrangeiros, nem augmentar aquelles, que se percebem, na exportaçaõ, ou na importaçaõ sobre estes mesmos navios: outro expediente póde haver mais suave, e d'hum effeito mais certo [...].

o unico meio mais efficaz para diminuir de alguma sorte a superioridade da Navegaçaõ dos estrangeiros, he o estabelecer a maior conveniencia possivel na Navegaçaõ. ${ }^{191}$

É verdade que no resto das linhas do capítulo, "concurrence" é traduzido como "concorrência". No entanto, é claro que "conveniência" é um termo muito mais abrangente e menos comprometedor do que o outro. No Diccionario da Lingua Portuguesa de Rafael Bluteau, o primeiro significado de "conveniência" é "utilidade, interesse, lucro, proveito", e não há indicação de que tenha sido empregada como sinônimo para competição. E o artigo "concurrencia" relata que "no comércio" isso significa "concurso das mesmas mercadorias". ${ }^{191}$

Em outra passagem "concurrence des capitaux"193 é surpreendentemente traduzido como "concorrência de capítulos" 194 , o que faz com o que o sucesso econômico dependa da competição entre ordens religiosas! O resultado geral é que a estratégia de "liberdade e concorrência" esteja presente, mas Pereira toma cuidado para evitar a cobrança de assumir uma postura contra a abordagem mais protecionista de Pombal à política comercial.

\footnotetext{
${ }^{190}$ id., p. 325-6, sem grifos no original.

191 [FORBONNAIS]... Elementos... II, p. 15-16, sem grifos no original.

192 BLUTEAU, Rafael. Diccionario da lingua portugueza, composto pelo padre D. Rafael Bluteau, reformado, e accrescentado por Antonio de Moraes Silva natural do Rio de Janeiro, 2 Vols, Lisboa: Na Officina de Simão Thaddeo Ferreira, 1789: I, p. 325; 304-5. sem grifos no original.

${ }^{193}$ [FORBONNAIS]... Élémens... p. 327.

${ }^{194}$ [FORBONNAIS]... Elementos... II, p. 17.
} 
Ainda mais interessante, todas as referências ao comércio de escravos são cuidadosamente omitidas ${ }^{195}$. Conforme mostrado acima, Forbonnais o considerava uma necessidade. Mas ele argumentava que a livre competição entre as nações era a melhor forma de comprá-los a preços baixos. Sabemos que o comércio de escravos era um dos negócios mais lucrativos da Companhia do Grão Pará e Maranhão ${ }^{196}$ e, provavelmente, Pereira tinha a intenção de evitar a crítica implícita que a estratégia de Forbonnais continha sobre esse assunto. Em todo caso, a passagem completa, que se estendia da linha 6 da página 382 até a linha 7 da página 386, não foi traduzida na versão em português. Essa passagem omitida também continha o ataque explícito de Forbonnais às companhias privilegiadas, que era obviamente algo que Pombal não gostaria de ler.

É possível que tal omissão fosse o resultado de uma censura preventiva. Mas, infelizmente não há documentação em arquivo que possa prová-lo. Existem, entretanto, evidências textuais de que qualquer referência crítica à Inquisição foi removida da tradução. Por exemplo, uma longa passagem na qual Forbonnais relata a opinião de Josiah Child de que o despovoamento da Espanha foi causado pela Inquisição muito mais do que pela emigração de nativos espanhóis para as colônias, foi omitida. ${ }^{197} \mathrm{Um}$ caso semelhante é o do capítulo 1, em que Forbonnais descreve a crise do comércio nos Países Baixos após a ascensão de Filipe II de Habsburgo ao trono. Enquanto Forbonnais escreve que o comércio "étoit immense dans ces provinces, lorsque Philippe II. le troubla par l'établissement de nouveux impôts \& de l'inquisition", ${ }^{198}$ Pereira traduz conforme segue: "Florescente se achava elle naquellas provincias quando Filippe II. o perturbou pelo establecimento de novos impostos, e pelo Catholico zelo, com que quiz purificar a Religiaõ". ${ }^{199}$ A propósito, essa passagem está incluída em uma explicação histórica, na qual a colonização portuguesa é levada em consideração. Forbonnais não poupa sua crítica à ação da monarquia portuguesa. Mas, significativamente Pereira não modifica essas partes do texto ${ }^{200}$.

\footnotetext{
${ }^{195}$ Por exemplo, a passagem em [FORBONNAIS]... Élémens... p. 289, afirmando que "[l]e bas prix dépendra encore du bon marché des Nègres, du fret, de l'intérêt de l'argent, tous effets de la concurrence des négocians" (sem grifos no original), foi traduzida omitindo esse item: "O baixo preço depende da moderaçaõ dos fretes, e do interesse do dinheiro, effeitos todos de concorrencia dos negociantes" [FORBONNAIS]... Elementos ... II, p. 54.

${ }^{196}$ COSTA, op. cit. p. 270-1.

${ }^{197}$ [FORBONNAIS]... Élémens... p. 378-9.

${ }^{198}$ [FORBONNAIS]... Élémens... p. 30, sem grifos no original.

${ }^{199}$ [FORBONNAIS]... Elementos... I, p. 25.

${ }^{200}$ Ver, por exemplo [FORBONNAIS]... Élémens... p. 34, onde o autor se refere a "les rois Indiens qui gemissoient sous le joug impérieux des Portuguais": uma observação pejorativa que é mantida pelo tradutor
} 
Há uma última questão em relação a essa tradução que merece algum comentário. Oferecendo-a a Pombal, Pereira declarou:

Offereço a V. Excellencia, vertidos no idioma Portuguez, os Elementos do Commercio, que compoz Carlos Seconda de Montesquieu, Varaõ que em tanto que no mundo existir a veneraçaõ dos Sabios, durará para sempre impresso na lembrança dos homens o seu nome [sic] pela grandeza das suas obras. ${ }^{201}$

Sabe-se que Élémens de Forbonnais foram publicados anonimamente. Pereira ignorava o real autor desse trabalho. A questão é por que ele se convenceu de que o autor era Montesquieu? Em The Passions and the Interests, Albert O. Hirschman chamou a atenção de estudiosos da chamada "tese do doux commerce" formulada por Montesquieu nos livros XX-XXI de Esprit de lois. Montesquieu argumentava que "c'est presque une règle générale, que partout où il y a des moeurs douces, il ya du commerce; \& que partout où il y a du commerce, il a des moeurs douces". ${ }^{202}$ Como consequência, "[l]'effet naturel du commerce est de porter à la paix. Deux nations qui négocient ensemble, se rendent réciproquement dépendantes: sil'une a intérêt d'acheter, l'autre a intérêt de vendre; \& toutes les unions sont fondées sur des besoins mutuels". ${ }^{203}$ O Esprit des lois foi certamente uma fonte para Forbonnais, que abriu seu tratado com algumas máximas que lembravam a tese do doux commerce:

La providence infinie dont la nature est l'ouvrage, a voulu par la variété qu'elle y répand mettre les hommes dans la dépendance les uns des autres. L'être suprême en a formé les liens, afin de porter les peuples à conserver la paix entr'eux, à s'aimer, \& afin de réunir le tribut de leurs louanges, en leur manifestant son amour \& sa grandeur, par la connoissance des merveilles dont il a rempli l'univers. C'est ainsi que les vues et les passions humaines rentrent dans l'ordre inaltérable des décrets éternels. ${ }^{204}$

Nenhuma tradução de chef-d'oeuvre de Montesquieu circulou em Portugal no século XVIII. A primeira tradução de Esprit des lois apareceu no Brasil somente em 1982. Um decreto da Real Mesa Censória de 22 April de

([FORBONNAIS]... Elementos... I, p. 28): “os Reis Indiáticos que gemiaõ debaixo do jugo imperiozo dos Portuguezes".

${ }^{201}$ [FORBONNAIS]... Elementos... s./p.

${ }^{202}$ HIRSCHMAN, Albert O. The Passions and the Interests: Political Arguments for Capitalism before Its Triumph, Princeton, NJ: Princeton University Press, 1977; MONTESQUIEU, Charles Secondat de. De l'Esprit des loix, nouvelle édition revue, corrigée, \& considérablement augmentée par l'auteur, 4 Vols, Londres: s.n. 1757 [1748], II, 238.

${ }^{203} \mathrm{id} .$, p. $239-40$.

${ }^{204}$ [FORBONNAIS]... Élémens... p. 1-2. 
1771 proibia a circulação e tradução de Lettres persanes ${ }^{205}$, enquanto traduções de Considérations sur les causes de la grandeur des Romains et de leur décadence e de "Pensées" publicadas no Journal encyclopédique datam de um período posterior (1780 e 1789, respectivamente). Entretanto, Pereira pode ter se familiarizado com o trabalho principal de Montesquieu no original em francês. Havia outras semelhanças entre Élémens e os dois livros de Esprit devotados ao comércio que podem ter capturado a atenção de Pereira: capítulo 1 do livro XX de Esprit foi intitulado "Du commerce", enquanto que o capítulo 1 de Élémens foi intitulado "Du commerce en général". A explicação histórica contida nesse capítulo foi claramente creditada ao livro XXI de Esprit. A análise da livre competição no capítulo 2 de Élémens mostrou alguns paralelos com os capítulos 12 e 13 do livro XX de Esprit, em que Montesquieu argumentava que "[l]a liberté du commerce n'est pas une faculté accordée aux négocians de faire ce qu'ils veulent; ce seroit bien plutôt servitude", ${ }^{206}$ e aprovava as medidas de protecionismos introduzidas pela GrãBretanha, concluindo que "[e]lle gêne le négociant; mais c'est en faveur du commerce". Os argumentos de Forbonnais' sobre a dependência colonial eram semelhantes aqueles contidos no capítulo 21 do livro XXI de Esprit. E os exemplos poderiam ser multiplicados ad libitum. Talvez o entendimento errado tenha sido criado pelo próprio Montesquieu, que no início do livro XX tinha dado a impressão que queria escrever um trabalho mais extenso sobre o assunto do comércio:

Les matières qui suivent demanderoient d'être traitées avec plus d'étendue; mais la nature de cet ouvrage ne le permet pas. Je voudrois couler sur une rivière tranquille; je suis entraîné par un torrent. ${ }^{207}$

Assim, Pereira traduziu Forbonnais acreditando que estava introduzindo o pensamento econômico de Montesquieu em seu país como uma contribuição à defesa e disseminação da política comercial de Pombal.

\section{A última defesa de Pombal por Pereira}

Vimos na seção 2 que, em 1768, Pereira foi nomeado Secretário da Junta da Administração da Companhia Geral do Grão Pará e Maranhão, e daquele

\footnotetext{
${ }^{205}$ Ver: Catálogo de livros defesos neste Reino ... para servir no Expediente da Casa da Revisão, ANTT, Real Mesa Censória, liv. 12, f. 43. Ver: MARQUES, Maria Adelaide Salvador. A Real Mesa Censória e a cultura nacional. Aspectos da geografia cultural portuguesa no século XVIII, Coimbra: s.n. 1963; MARQUES, Maria Adelaide Salvador. Pombalismo e cultura média: meios para um diagnóstico através da Real Mesa Censória, Lisboa: s.n., 1982; and MARCOCCI, Giuseppe, and PAIVA, José Pedro. História da Inquisição Portuguesa 1536-1821, Lisboa: A Esfera dos Livros, 2013, para uma análise da censura em Portugal no século XVIII.

${ }^{206}$ MONTESQUIEU, op. cit. II, p. 253-4.

${ }^{207} \mathrm{id}$., p. 238.
} 
momento em diante ele lealmente promoveu os objetivos da Companhia, deixando de lado as propostas que a contradiziam. Após a queda de Pombal em 1777, entretanto, as novas políticas comerciais adotadas por D. Maria I, especialmente de liquidação das Companhias Comerciais e seu monopólio, provocaram uma vez mais uma reflexão sobre o futuro da economia portuguesa. Era natural que os protagonistas das reformas econômicas pombalinas, entre eles Pereira, tentassem defender a ação e papel dessas instituições.

Foi nessa época que o Secretário da Companhia decidiu compor um original terceiro volume das Aventuras de Telémaco, anexado à segunda edição de sua tradução ${ }^{208}$. O título desse volume era: Aventuras Finaes de Telemaco, Filho de Ulysses. Inocêncio da Silva reservou um comentário irônico a esse trabalho: "É parto original do traductor, destinado por elle a completar a obra de Fenelon, que no seu entender carecia de remate, faltando-lhe o casamento do heróe!". ${ }^{209}$ Essa observação provavelmente desencorajou os leitores do século XIX e XX de examinarem tal trabalho "filisteu".

O comentário de Inocêncio foi largamente apropriado pelas partes "privadas" da continuação de Pereira: os casamentos entre Telêmaco e Antíope, seus dois filhos, o (menino) que nasceu primeiro, Telemaquion, e a filha Anaxibéa. Entretanto, as Aventuras Finaes continham duas partes políticas bem intrigantes, que merecem alguma atenção pela reconstrução presente das visões política e econômica de Pereira. O livro XXIX ${ }^{210}$ descreve as reformas introduzidas por Ulisses em Ítaca após o retorno de sua peregrinação e restauração do poder sobre os pretendentes de Penélope. E na conclusão, os livros XXXI e XXXII contém uma detalhada instrução dada por Ulisses a Telêmaco sobre como tornar um reino forte e feliz, após a sua decisão de abdicar para "passar o resto [da sua vida] com mais socego, na companhia da

\footnotetext{
${ }^{208}$ FÉNELON, François de Salignac de la Mothe. Aventuras de Telemaco, Filho de Ulysses, 2a ed. corecta e adicionada pelo mesmo tradutor da primeira versão das ditas aventuras, t. 1, Lisboa: Na Offic. De José De Aquino Bulhões, 1785; t. II, Lisboa: Na Offic. de Lino da Silva Godinho, 1784; t. III, Aventuras Finaes de Telemaco, Filho de Ulysses, novamente compostas pelo bacharel Joseph Manoel Ribeiro Pereira, Secretario da Junta da Administraçaõ da Companhia Geral di Graõ Pará, e Maranhaõ, para serverem de continuaçaõ, e supplemento ás que em França compoz o sabio, e illustre Fenelon, e que já se achaõ traduzidas em Portuguez pelo mesmo Author desta nova composiçaõ, Lisboa: Na Offic. de Lino da Silva Godinho, 1785. Inocêncio da Silva menciona a segunda edição em dois volumes da tradução de Pereira datada de 1780. Não há razão para duvidar que essa edição existiu, embora não a tenhamos encontrado nas bibliotecas portuguesas. Entretanto, a página inicial da edição de 1784-1785 declara ser esta a segunda (modificada) edição da tradução. Provavelmente a versão de 1780 foi apenas uma reimpressão da primeira edição. Também António A. Gonçalves Rodrigues (op. cit.) menciona a edição de 1780 apenas se baseando na informação de Silva.

${ }^{209}$ SILVA, op. cit. p. 9.

${ }^{210}$ Também a numeração dos livros inicia no ponto em que Fénelon tinha chegado.
} 
sua querida Penelope, por ver se assim tambem vencia o seu destino, e evitava a ser morto por seu proprio filho, conforma Tiresias lhe tinha vaticinado". ${ }^{211}$

O livro XXIX contém um discurso pronunciado por Minerva, agora agindo diretamente como uma personagem do romance, no qual ela dita um plano para a constituição de Ítaca. Entre suas recomendações há a promoção da agricultura baseada em vantagens competitivas locais ${ }^{212}$ e das fábricas "pelas multiplicadas utilidades que resultaõ aos povos de similhantes establecimentos, assim pela indipendencia em que se constituem de outros povos, como pelo emprego dos homens, e maior augmento do Commercio geral do Estado" ${ }^{213}$ Mas a parte principal do capítulo é representada pela descrição das reformas introduzidas por Ulisses, agora sistematicamente acompanhadas por Telêmaco e, mais interessantemente, "ajudado dos prudentes conselhos do grande Eurybato, (hum dos companheiros de Ulysses, que os Deoses tinhaõ preservado de todos os perigos, e que depois de ter corrido differentes climas, tinha ido parar a Creta, onde achando um navio dos Pheacios, se embarcou nelle para Ithaca, para ter o gosto de tornar a ver seu amo, e ajuda-lo á reforma de que necessitava o Reino)". ${ }^{214}$

Nenhum leitor contemporâneo deixaria de perceber que Telêmaco apareceu nesse capítulo como uma personificação de D. José, o neto de D. José I, na época príncipe do Brasil (que, incidentalmente, tinha sido objeto de uma última tentativa de Pombal de persuadir D. Maria I, sua mãe, a abdicar em seu favor ${ }^{215}$ ), enquanto Euríbates era um avatar do marquês de Pombal. Mas é perceptível que essa dramatização foi proposta oito anos após a queda e prisão de Pombal, e sete anos após a extinção da Companhia do Grão Pará e Maranhaõ. Mais provavelmente, Pereira intencionalmente decidiu publicar a seu modo uma defesa ex-post do Marquês e uma apologia orgulhosa da extinta Companhia que ele ainda gerenciava. Mas, se é uma verdade objetiva que as Aventuras Finaes foram publicadas em 1785, ainda não está claro quando elas foram realmente escritas, ou se havia uma primeira edição publicada antes de 1777 que se perdeu. Vamos começar a partir da segunda pergunta. $\mathrm{Na}$ verdade, a página inicial do "volume três" da edição de 1785 a descreve como "segunda edição".

\footnotetext{
${ }^{211}$ FÉNELON... Aventuras Finaes de Telemaco, p. 213.

${ }^{212} \mathrm{id}$., p. 142.

${ }^{213} \mathrm{id}$., p. $142-3$.

${ }^{214} \mathrm{id}$., p. 156-7.

${ }^{215}$ MARQUES, op. cit. p. 372-3.
} 
Agora, há duas explicações possíveis para tal anotação: ou houve mesmo uma primeira edição de Aventuras Finaes que desapareceu, ou a frase "segunda edição" se refere aos três volumes da edição de 1784-1785 como um todo (a mesma frase aparece nas páginas iniciais dos vol. 1 e vol. 2). Mas, se houve uma primeira edição do vol. 3, essa foi quase que certamente após 1780, conforme Inocêncio da Silva descreve a versão publicada naquele ano era uma edição em dois volumes. ${ }^{216}$ Ele também considera a edição de 1785 de Aventuras Finaes como a primeira edição desse trabalho.

Mas o romance de Pereira foi escrito antes ou depois de 1777? Há diversas notas de rodapé no capítulo XXXII que se referem a Pombal e José I respectivamente como ministro atual e rei atual de Portugal ${ }^{217}$. Isso parece sugerir que o texto foi escrito antes de 1777, e não foi modificado quando o livro foi publicado em 1785. Foi isso uma falta de cuidado ou uma estratégia intencional de "dissimulação honesta", objetivando preservar a eulogia ao governo de Pombal sob a coberta dos pensamentos formulados sob um clima político diferente, que agora parecia mera evidência histórica? Um argumento em favor do descuido é a pouca qualidade de edição do livro. Há diversos erros de impressão e inconsistências, como se o autor não tivesse tido o cuidado de revisar. É possível que ele esqueceu de atualizar as notas de rodapé que se referiam a eventos passados, e ele não as notou quando revisou o texto para impressão, ou que ele simplesmente não se importasse em modificá-las. Mas o secretário do conselho de diretores da Companhia não poderia ser ingênuo ao considerar as consequências políticas de tal omissão. E mesmo a hipótese alternativa de que o livro tenha sido impresso antes de 1777, e publicado apenas mais tarde, não nos permite excluir que houve uma parte de dissimulação proposital ao deixar os elogios a Pombal e suas políticas não modificadas ${ }^{218}$.

\footnotetext{
${ }^{216}$ SILVA, op cit. p. 9.

${ }^{217}$ A nota $(t)$ na p. 285 refere-se a uma passagem recomendando o encorajamento da exportação, e preconiza: "Systema este onde tendem todas as vistas politicas, e economicas do nunca assaz louvado Ministerio de Portugal". A nota (u) na p. 287, comenta a sugestão de reduzir ou eliminar os encargos no comércio interno, declara: "Maxima esta que constitue o espirito de muitas, e repetidas Leis promulgadas no actual, e felicissimo Reinado do Senhor Rei D. Joseph o I". A nota (y) na p. 288, referindo-se a recomendação de Ulisses de honrar o comércio, afirma: "Doutrina assaz authorizada nos publicos testimunhos de honra, com que o nosso amabilissimo Monarca tem ondecorado esta Profissaô". A nota (z), p. 289, comentando a opinião que ao proteger o comércio o Rei deveria ser apoiado pelo conselho dos "Negociantes mais habeis", refere-se à Junta de Comercio criada por Pombal nos seguintes termos: "Maxima neste Reino praticada pelo establecimento da Junta de Commercio, Tribunal de quem emanaõ todas as decisões mercantis". Finalmente, a nota (a), p. 290 refere-se à política de substituição à importação de Pombal através das fábricas estabelecidas pelo governo, e comenta que a negligência de tal questão tem sido "providamente acautelada pelas innumeraveis Fabricas estabecidas neste Reino para consumo dos generos do mesmo payz".

${ }^{218} \mathrm{Há}$ uma outra hipótese ainda mais criativa: Pereira pode ter fingido ter escrito o livro quando Pombal
} 
Na verdade, seguindo o conselho de Euríbates, Ulisses cria uma marinha forte para defender Ítaca e as ilhas que estavam sob seu poder (ou seja. suas colônias!). ${ }^{219}$ Então ele motiva o comércio "com regalias, e privilegios", aumentando o respeito "naõ só dos seus naturaes, mas ainda dos outros povos de Argos, com os quaes começeraõ huma nova correspondencia, bem differente nos interesses á que antes com elles conservavaõ". ${ }^{220}$ Foi fácil para os leitores contemporâneos reconhecer por trás de Argos um simulacro da Grã-Bretanha, o último alvo dos esforços de Pombal para proteger o comércio português. Imediatamente após, Euríbates aconselha Ulisses a proteger as fábricas, e a expulsar de Ítaca aqueles corruptos e infiéis "Sacrificadores" (claramente os Jesuítas) que tinham tentado criar um poder independente em casa e nas colônias, ameaçando o poder supremo do príncipe e combatendo suas tentativas de reformas. Como consequência, Ulisses tinha reformado a educação, um monopólio prévio dos "Sacrificadores", colocando-a sob a proteção do Estado. ${ }^{221}$

Assim se conservavaõ todas as differentes classes, concorrendo de maõ
commum á utilidade publica. Banida a inveja dos corações, tanto se estimava
a commodidade alheia, como a propria. Temeroso o engano do rigor das Leis
naõ ousava a formar suas ordinarias caballas contra a boa fé do Commercio. As
riquezas vendo o bom uso que dellas se fazia em Ithaca, corriaõ como de tropel
a entrarem pelo porto, com tanta abundancia, que em pouco tempo pela sua
opulencia começou a excitar o ciume das nações mais poderosas de Grecia. ${ }^{222}$

Não havia quase nenhum ponto em comum entre essa defesa dissimulada das políticas de Pombal e a economia anti-luxo, pacifista e de livre comércio de Fénelon, exceto a ideologia básica do século XVIII da monarquia como responsável pela opulência e poder da nação. Mas, há ainda um outro questionamento nessa história. Pereira escolhe Euríbates, companheiro de Ulisses, como avatar de Pombal. Essa escolha vai contra uma tradição que vai da f́liada de Homero à Comédia de Dante, que associa Ulisses a Diomedes. No canto 26 do Inferno, ambos são condenados ao inferno como "conselheiros da fraude" pela forma na qual eles convenceram os gregos a tomar Tróia pela força. Mas

estava no poder, para justificar seu elogio como um aparente esquecimento. Mas tal intencionalidade Maquiavelica se opõe ao espírito anti-maquiavelico do livro, que enfatiza a necessidade de um rei ser honesto e amar a verdade em todas as circunstâncias. Ver, por exemplo FÉNELON... Aventuras Finaes de Telemaco, p. 232-237.

${ }^{219}$ id., p. 159.

${ }^{220} \mathrm{id} .$, p. 161.

${ }^{221}$ id., p. 161-5.

${ }^{222}$ id., p. 166. 
Dante os considera magnânimos e leais aos seu país. O caso de Euríbates é diferente: um Eurybates é, na verdade, mencionado na Odisséia como escudeiro de Odisseu, "e Odisseu o honrava acima dos seus outros camaradas, porque eles pensavam da mesma forma". Entretanto, há toda uma tradição na cultura Européia que associa o nome de Euríbates com a protótipo do traidor e vigarista. Por exemplo, Diodorus Siculus em sua Bibliotheca ${ }^{223}$ descreve o caso de um "Euribates de Éfeso", que foi despachado por "Creso, rei da Lídia, [...] ao Peloponeso, dando-lhe dinheiro com o qual recrutar quantos mercenários ele pudesse entre os gregos. Mas esse agente de Creso foi ter com Ciro da Pérsia e revelou-lhe o plano. Consequentemente a iniquidade de Euríbates tornou-se conhecida entre os gregos, e a partir daquele dia quando um homem quer acusar outro de canalha ele o chama de Euríbates"224. E Erasmo de Roterdam em seu Adagia, ${ }^{225}$ mencionando diversas fontes, incluindo Homero, define o verbo "euribatizar" ("fazer como Euríbates") como uma forma proverbial de indicar feitos imorais e criminosos de diversos tipos, incluindo traição e corrupção ${ }^{226}$. É pouco provável que Pereira ignorasse essa tradição, dado seu profundo conhecimento dos clássicos que brilham em cada página do seu "romance". Mas podemos supor que essa apresentação aparentemente elogiosa de Euríbates dissimulasse um elogio moral negativo a Pombal? Tal hipótese parece difícil de acreditar, considerando que Pereira ainda estava na posição que o Secretário de Estado o tinha nomeado. Mas é, no entanto, possível que ele estivesse consciente de que o clima político tinha mudado sob o comando de D. Maria e, sem necessariamente, compartilhar do ponto de vista da nova corte, ele deixou uma porta aberta àqueles que acreditavam que Pombal fosse corrupto e um inimigo da ordem social tradicional. A escolha de Euríbates como um apelido para Pombal poderia ser uma forma de admitir que suas políticas sábias podiam ser um produto de uma mente que, aos olhos de muitos, era inescrupulosa e tirânica. Ou talvez foi simplesmente uma tática de elogiar livremente sem ser acusado de propaganda antipatriótica.

De qualquer forma, uma abordagem político econômica ao comércio semelhante é apresentada no que parece ser um testamento político de Ulisses:

\footnotetext{
${ }^{223}$ DIODORUS SICULUS. The Library of History, with an English translation by C. H. Oldfather, Cambridge, MA and London: Harvard University Press, 2004-9, p. 32.

${ }^{224}$ Ver: http://www.perseus.tufts.edu/hopper/text?doc=Perseus:text:1999.01.0084:book=9:chapter=32\& highlight=eurybatus

${ }^{225}$ ERASMUS OF ROTTERDAM. “Adagia”. In: Desiderii Erasmi Roterodami opera omnia emendatiora et auctiora [...], t. 2, Lugduni Batavorum: Cura et impensis Petri Vander A.1703, I, II, p. 86.

${ }^{226}$ Ver: http://sites.univ-lyon2.fr/lesmondeshumanistes/wp-content/uploads/2010/09/Adages-tome-1.pdf
} 
as "sábias, e discretas instrucções para bem reinar, e para fazer feliz o seu Reino, e o seu povo" ditada a Telêmaco nos últimos dois livros de Aventuras Finaes. ${ }^{227}$

O sistema muito mais abrangente naquela época, como a análise das obrigações econômicas de um rei sábio é precedida no livro XXXI por uma teoria detalhada das origens do governo como um remédio ao estado permanente de guerra entre os homens. ${ }^{228} \mathrm{Em}$ tal condição - continua o argumento - os indivíduos aceitariam facilmente se subordinar "a huma autoridade que lhes tirasse huma parte da sua libertade, pare lhes conservar a outra parte". ${ }^{229}$ Essa passagem claramente ecoa as teorias políticas de Montesquieu e Rousseau, embora Pereira imediatamente especifique que tal argumento funciona como uma justificativa da monarquia absoluta, e do direto de governar que o rei deriva de Deus (“[o] Soberano dos Deoses”, no léxico de Ulisses') como seu representante na terra. ${ }^{230}$ Mas o objetivo final de uma soberania é o bem de seus súditos, "pois quem nasce para mandar, nasce para os outros, e naõ para si”. ${ }^{231}$ Para governar "pela razaõ", um rei deve conhecer seus súditos. Dessa forma ele será capaz de empregar o melhor estímulo para promover o bem comum. ${ }^{232}$ E esses estímulos estão baseados no desejo universal de felicidade:

Verás por experiencia propria quanto todos desejaõ ser felices; que todos tem este desejo em tudo quanto fazem; que todos se unem para ver se assim conseguem melhor este fim pelo mutuo soccorro que se communicaõ; que só, pela esperança de serem mais tempo felices, e com mais segurança, he que se sujeitaõ a hum Rei que lhe procure os meios, e que lhe possa vencer todos os obstaculos que elles particularmente naõ poderiaõ surmontar. ${ }^{233}$

Outro elemento que revela a familiaridade de Pereira com o Iluminismo é o igualitarismo no qual sua perspectiva se baseia. Nenhum privilégio deve ser admitido, e o rei, a aristocracia e o pobre são iguais em todos os aspectos. ${ }^{234}$ Para conhecer seus súditos, o rei deve esforçar-se a dotar o seu ponto de vista, e tentar sentir-se como eles se sentem. ${ }^{235}$ As recompensas devem

\footnotetext{
${ }^{227}$ FÉNELON... Aventuras Finaes de Telemaco, p. 212.

${ }^{228} \mathrm{id}$., p. 214-5.

${ }^{229}$ id., p. 214.

${ }^{230} \mathrm{id}$., p. 216.

${ }^{231}$ id., p. 217.

${ }^{232} \mathrm{id}$., p. 221.

${ }^{233}$ id., p. 225-6.

${ }^{234} \mathrm{id}$., p. 260.

${ }^{235} \mathrm{id}$., p. $227-8$.
} 
ser concedidas de acordo com o mérito, não nascimento ou favor. ${ }^{236}$ Pereira endossa totalmente a desconfiança de Pombal em relação à aristrocracia:

Naõ desprezarás infinitas cousas que ordinariamente escapaõ á ponderaçaõ dos Grandes; porque elles naõ se põe [sic] nunca no lugar dos pequenos, e já mais se persuadem que os outros homens tem a mesma sensibilidade que elles. ${ }^{237}$

Não é de se surpreender que após uma análise detalhada das qualidades necessárias aos conselheiros do Rei, Pereira concluiu que o ministro perfeito é "hum homem tal come Eurybato, digno de ser teu amigo, como elle o foi meu". ${ }^{238}$ Se no livro XXXI Ulisses diz a Telêmaco "qual deves ser", no livro XXXII ele examina "o que deves fazer para bem governares o teu povo". ${ }^{239}$ É aqui que encontramos as opiniões de Ulisses sobre economia política. Interessantemente, a lista da agenda é iniciada com uma indicação de aplicar a cada circunstância a Regra de Ouro: "Primeiro que tudo deves tratar os teus vassallos como quizeras ser tratado se obedeceras". ${ }^{240}$ Então, seguir uma lista das obrigações principais da soberania: visitar seu país e ter um conhecimento direto das condições de cada classe, também como forma de aprender "que a tua principal obrigaçaõ he o amor do teu povo", ${ }^{241}$ e fazer um estudo estatístico detalhado de seus domínios. Esse estudo é necessário para saber o caráter e costumes de cada província, que conjuntamente formam "o que se chama caracter geral da Naçaõ", ${ }^{242}$ os aluguéis pagos no país, para entender quando eles podem ser aumentados ou devem ser reduzidos pelo bem da nação, ${ }^{243}$ a situação do comércio interno e como ele pode ser facilitado pelo governo através da construção de estradas, canais, e promovendo segurança e transparência, ${ }^{244}$ a produtividade de diferentes terras, seja esta última resultado da natureza ou de "omissaõ”, a população de várias áreas para entender como apoiar aquelas que estão com excesso de população ao fornecer gado e sementes. ${ }^{245} \mathrm{~A}$ lista de obrigações continua com a administração da

\footnotetext{
${ }^{236} \mathrm{id} .$, p. $253-4$.

${ }^{237} \mathrm{id} .$, p. 227.

${ }^{238} \mathrm{id} .$, p. 242.

${ }^{239}$ id., p. 259.

${ }^{240} \mathrm{id} .$, p. 260.

${ }^{241}$ id., p. 261.

${ }^{242}$ id., p. 264-5.

${ }^{243} \mathrm{id}$., p. $265-6$

${ }^{244}$ id., p. 266.

${ }^{245} \mathrm{id} .$, p. $266-7$.
} 
justiça, necessária para garantir a Lei, ${ }^{246}$ e finalmente com a economia política, um braço da arte de governar que é culturalmente modelada na oikonomìa de Aristóteles:

...pois assim como hum pai de familias, attento ao seu bem, e ao dos seus filhos, he a imagem mais natural de hum Rei attento ao bem dos sues vassallos, e do seu Reino, assim a economia do primeiro em conservar, e augmentar o que recebeo de seus pais, o seu desvelo, e amor pela tua [sic] familia, saõ o modelo de tudo o que deve fazer o Pai do Povo. ${ }^{247}$

A agricultura deveria ser promovida porque garante a independência nacional. ${ }^{248}$ Ulisses tem um olhar favorável às pequenas propriedades, que estimulam a produtividade e fortalecem o sentimento de patriotismo. ${ }^{249} \mathrm{Tal}$ condição deve ser encorajada mantendo o aluguel baixo ${ }^{250}$, de forma que os camponeses possam economizar dinheiro para comprar um pequeno pedaço de terra, e fornecendo gado e sementes no caso de falta. Outra forma de encorajar a agricultura era persuadir a aristocracia a cuidar pessoalmente do gerenciamento de suas terras. Tal abordagem ecoa os esforços de Pombal de enfraquecer os privilégios tradicionais para favorecer uma maior mobilidade da propriedade de terras, ${ }^{251}$ bem como a circulação das literaturas britânica e francesa em agronomia, que continham recomendações semelhantes ${ }^{252}$.

Em relação ao comércio, a proteção que Ulisses recomendava é inspirada na "inveja do comércio": que se baseia na redução das importações e aumento de exportações, para manter o dinheiro dentro do país, exportar o excedente da produção nacional e promover a indústria doméstica ${ }^{253}$. A proteção das fábricas é baseada na estratégia de substituição da importação, "pois será cousa bem reprehensivel deixares passar a mãos estranhas o que

\footnotetext{
${ }^{246} \mathrm{id}$., p. 268-78.

${ }^{247}$ id., p. $278-9$.

${ }^{248} \mathrm{id}$., p. $279-80$.

${ }^{249} \mathrm{id}$., p. $280-2$.
}

${ }^{250}$ Pereira emprega o termo "pensões", ou seja, os aluguéis pagos em contratos de arrendamento, que eram típicos da agricultura portuguesa no século 18, especialmente ao norte de Tagus. Ver: COSTA, op. cit. p. 222-3.

${ }^{251}$ COSTA, op. cit. p. 221-2.

${ }^{252}$ Uma prova dessa circulação é a tradução em 1788 de Élémens d'agriculture, fondés sur les faits et les raisonnements, à l'usage du peuple de la campagne (1775) de Jean Bertrand, um trabalho que ganhou um premio concedido pela Société économique de Berna em 1774.

${ }^{253}$ FÉNELON... Aventuras Finaes de Telemaco, p. 285: "He preciso para ser feliz hum Reino, que necessite pouco dos outros, e que os outros naõ possaõ deixar de commerciar com elle: de outra sorte se exahurirá o dinheiro, naõ tendo nada que vender, e virá a ficar pobre se tiver que comprar tudo o que necessitar aos mais". 
podia ser manufacturado pelas dos teus vassallos". ${ }^{254}$ As políticas industriais objetivavam maximizar o emprego e evitar a saída de dinheiro, mesmo que isso reduzisse a eficiência e aumentasse os preços. Apenas a importação de matéria prima seria admitida. ${ }^{255} \mathrm{O}$ rei deveria moderar a concorrência interna ao proibir o estabelecimento de novas fábricas em indústrias já estabelecidas. Inovações que reduzissem a demanda de mão-de-obra seriam igualmente desencorajadas, ${ }^{256}$ uma vez que "[o] teu maior cuidado ha de ser que todos vivaõ occupados, e possaõ ganhar pelo seu trabalho com que se sustentem". ${ }^{257}$ Ulisses chegava a recomendar a concessão de premios para invenções, mas proibia sua implantação, se elas reduzissem o emprego e fossem prejudiciais aos pobres. A distância entre o seu ideal de industrialização regulada e a abordagem de mercado aberto de Fénelon pode ser medida pelas considerações finais de Pereira em relação à concorrência:

...destes dois grandes males [desemprego e preguiça] he mui tenue a compensaçaõ de ter as cousas por melhor preço, pois esta diminuiçaõ he mui pouco sencivel, ao mesmo tempo que he mui pezado o encarego a que fica sujeito o Estado com huma multidaõ inutil..$^{258}$

Também a atitude de Ulisses em relação ao luxo é ambígua e bem distante do ponto de vista de Fénelon: o luxo extremo deveria ser desencorajado, ${ }^{259}$ mas poderia as vezes ser tolerado "pelo bem do Commercio", embora não "alem dos limites, que a utilidade publica lhe prescrever". 0 tipo de artigos de luxo que poderiam ser permitidos são aqueles "que servirem á navegaçaõ, ao fabrico das lãas, sedas e armas, e a todas, em fim, que sendo materia do Commercio, contribuem a occupar utilmente o povo, e a exercitar o seu trabalho, e industria, banindo do Reino a ociosidade, e a indigencia". ${ }^{260}$ Finalmente, o rei deveria promover as ciências mais pelo prestígio que elas garantem do que por suas aplicações práticas. ${ }^{261}$

\footnotetext{
${ }^{254}$ id., p. 289-90.

${ }^{255} \mathrm{id}$., p. 290.

${ }^{256} \mathrm{id}$., p. $290-1$.

${ }^{257}$ id., p. 291.

${ }^{258}$ Ibid.

${ }^{259} \mathrm{id}$., p. 292-3.

${ }^{260}$ id., p. 295.

${ }^{261} \mathrm{id}$., p. 293-5.
} 
O resto do livro é dedicado à defesa, a obrigação final da soberania. Esse ítem permite que Pereira examine o tópico dos impostos. ${ }^{262}$ Os impostos são um atributo da soberania e devem ser obedecidos sem exceção. No entanto, o rei tem o dever de cobrar impostos moderados e manter a exata proporção entre os impostos e os gastos. ${ }^{263}$

Fica claro que a consistência entre os livros I e II, aqueles traduzidos em 1765 e republicados em 1784-1785, e o livro III, a criação original de Pereira, era muito fraca, especialmente nas questões de economia política, na qual ele decididamente estava agora do lado do Marquês.

\section{Conclusões}

A reputação de Pereira foi severamente questionada no século XIX pelo poeta Francisco Manuel do Nascimento e por Inocêncio da Silva, cujo comentário lapidar soava como: “Todas estas traducçoes, feitas no gosto da do Telemaco, são tidas na mesma conta. Ninguem as procura, ninguem as lê". ${ }^{264}$ À luz da oposição de Inocêncio à paráfrase e do desprezo que ele demonstrou pelo talento literário de Pereira, essa conclusão não é surpreendente. Entretanto, talvez seja muito dura ao menos se considerarmos a contribuição que Pereira deu à disseminação da economia política em Portugal no século XVIII. Com o provável consenso de Pombal, ele foi capaz de oferecer a tradução de dois trabalhos, Les Aventures de Télémaque e Élémens du commerce, que contribuíram com um limitado e severamente controlado apesar de aberto debate sobre as estratégias comerciais do Marquês em um estágio crítico de sua execução, quando as mudanças nas alianças e fluxos comerciais que se seguiram à Paz de Paris tornavam o futuro incerto. A liberação temporária da censura concedida pelo Secretário de Estado provavelmente objetivava estimular as respostas que poderiam ajudar a reajustar suas políticas em uma nova conjuntura.

Por outro lado, a continuação de Aventuras de Telémaco de Pereira, publicada em 1785 foi um tímido sinal de resistência de um partido pombalino na elite econômica de Portugal, e contribuiu para fortalecer a indecisão do governo de D. Maria I nessa área, terminando como uma continuidade substantiva do passado. ${ }^{265}$

\footnotetext{
${ }^{262}$ id., p. 297.

${ }^{263}$ id., p. 298-9.

${ }^{264}$ SILVA, op. cit. p. 10.

${ }^{265}$ MARQUES, op. cit. p. 373; COSTA, op. cit. p. 276.
} 